\author{
UNIVERSIDADE DE SÃO PAULO \\ Faculdade de Medicina de Ribeirão Preto \\ Programa de Pós-graduação em Bioquímica
}

Ana Carla Medeiros

Caracterização subcelular e bioquímica da proteína SAMHD1

Ribeirão Preto/SP 
ANA CARLA MEDEIROS

\section{Caracterização subcelular e bioquímica da proteína SAMHD1}

Tese de doutorado apresentada ao Programa de Pós-graduação em Bioquímica como parte dos requisitos para obtenção do título de Doutor em

Ciências, área de concentração Bioquímica

Orientador: Prof. Dr. Marcelo Damário Gomes

Co-orientador: Prof. Dr. Felipe Roberti Teixeira 


\begin{abstract}
AUTORIZO A REPRODUÇÃO E DIVULGAÇÃO TOTAL OU PARCIAL DESTE TRABALHO POR QUALQUER MEIO CONVENCIONAL OU ELETRÔNICO, PARA FINS DE PESQUISA, DESDE QUE CITADA A FONTE.
\end{abstract}

FICHA CATALOGRÁFICA

Medeiros, Ana Carla

Caracterização subcelular e bioquímica da proteína SAMHD1

Tese apresentada ao Programa de Pós-Graduação em Bioquímica da FMRP/USP. Departamento de Bioquímica e Imunologia.

Ribeirão Preto - Agosto 2019. 93p.

Orientador: Dr. Marcelo Damário Gomes

Co-Orientador: Dr. Felipe Roberti Teixeira

1- SAMHD1, 2- Início alternativo de tradução, 3- DSBs 


\section{FICHA DE APROVAÇÃO}

\section{Ana Carla Medeiros}

Caracterização subcelular e bioquímica da proteína SAMHD1

Tese apresentada ao Programa de PósGraduação em Bioquímica como parte dos requisitos para obtenção do título de Doutor em Ciências.

Área de concentração: Bioquímica

Aprovado em:

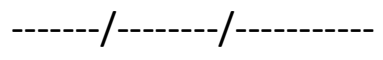

\section{Banca examinadora}

Prof. Dr. Marcelo Damário Gomes

Ass:

Faculdade de Medicina de Ribeirão Preto - FMRP/USP

Prof. Dr. Emer S. Ferro

Ass:

Instituto de Ciências Biológicas - ICB/USP

Prof. Dr. Adriano Silva Sebollela

Ass:

Faculdade de Medicina de Ribeirão Preto - FMRP/USP

Prof. Dr. Malson N. Lucena

Ass.

Universidade Federal de Goiás - UFG 


\section{AGRADECIMENTOS}

A Deus, por estar sempre me iluminando e abençoando;

A minha família, em especial aos meus pais pelo amor incondicional, apoio e incentivo de sempre buscar alcançar meus sonhos e objetivos;

Ao Bruno, pela paciência, incentivo, amor e por todos os momentos juntos;

Ao Marcelo, pela confiança em me receber em seu laboratório, pelos seus ensinamentos e por contribuir para minha formação profissional;

Ao Felipe, pela paciência, amizade, pelos puxões de orelha que tanto contribuíram para este trabalho, e por todos os seus ensinamentos acadêmicos e pra vida;

Aos meus amigos por todos os momentos de alegria e descontração fora do laboratório;

A Pri, minha companheira de bancada em todos esses anos! Obrigada pela paciência, amizade, conselhos pra vida, e por estar sempre presente;

Ao Prof. Cláudio, por nos permitir fazer uso do seu laboratório, assim como seus alunos por estarem sempre disponíveis a ajudar;

A todos os técnicos e funcionários do Departamento de Bioquímica pela gentileza de sempre, em especial a Cacilda pelo carinho de mãe e exemplo de bom coração;

A Capes pelo auxílio;

A FAPESP, CNPq pelo auxílio ao projeto;

E a todos que de alguma forma contribuíram para conclusão desta etapa, o meu muito obrigada! 
SUMÁRIO

RESUMO

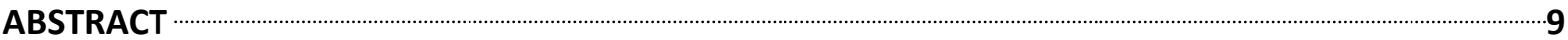

LISTA DE ABREVIAÇÕES

1. INTRODUÇÃO

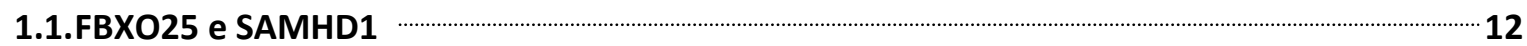

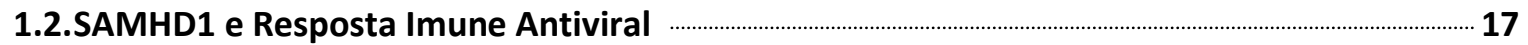

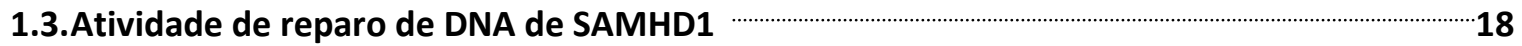

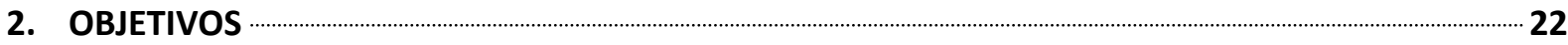

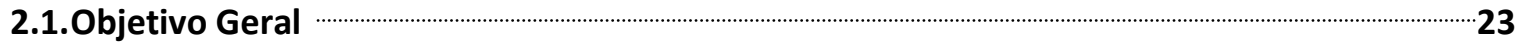

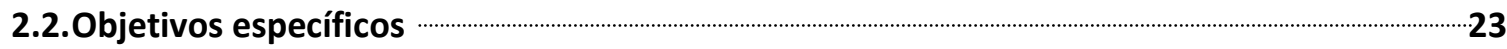

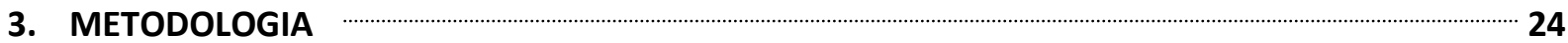

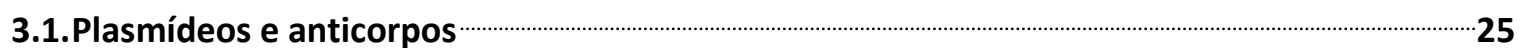

3.2.Subclonagem e mutagênese

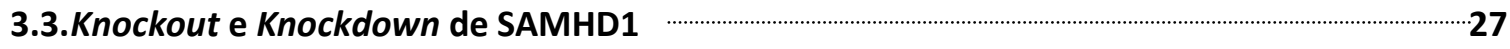

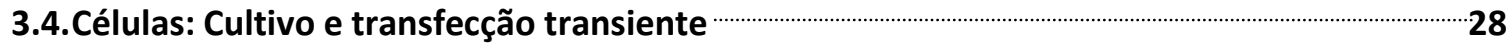

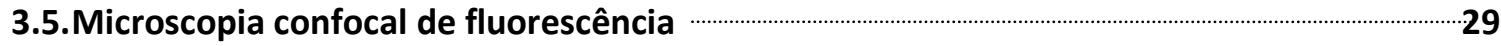

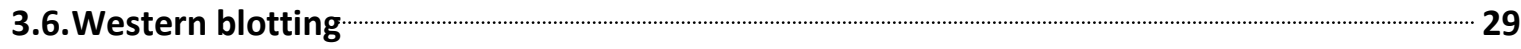

3.7. Ligação do anticorpo SAMHD1 a resina conjugada a uma mistura de proteína A/G usando Dimethylpimelimidate (DMP), para imunopurificação ……………………………………………………….... 30

3.8. Identificação de reatividade cruzada do anti-SAMHD1 Origene utilizando o Protoarray ……32

4. RESULTADOS

4.1.Especificidade do anticorpo anti-SAMHD1 (Origene Technologies) em diferentes linhagens celulares não mielóides. 35

4.2.A hiperexpressão de SAMHD1-HA gera uma proteína SAMHD1 truncada por tradução alternativa do sítio de iniciação 
4.3.SAMHD1 tem localização nuclear e é recrutada para locais onde há dano no DNA, causada por Camptotecina (CPT) 49

4.4.Avaliação da produção de SAMHD1(ATG2) endógena 54

4.5.Imunopurificação das proteínas reativas ao anticorpo anti-SAMHD1 monoclonal 56

4.6. Determinação da especificidade do anticorpo anti-SAMHD1 monoclonal utilizando microarranjos de Proteína (Protoarrays ${ }^{\circledR}$ ) 60

5. DISCUSSÃO 65

6. CONCLUSÕES 72

7. REFERÊNCIAS BIBLIOGRÁFICAS 74

8. ANEXOS 81

8.1.Sequenciamento da célula HAP1 knockout para SAMHD1 82

8.2. Proteínas com reatividade cruzada com o anticorpo monoclonal anti-SAMHD1 Origene Technologies, identificadas com o Protoarray ${ }^{\circledast}$ 83 


\section{RESUMO}

\section{Caracterização subcelular e bioquímica da proteína SAMHD1}

Medeiros, A. C., 2019.

Tese de doutorado 93p. Programa de Pós-graduação em Bioquímica da FMRP/USP.

SAMHD1 é uma proteína de 626 aminoácidos com um motivo $\mathrm{N}$-terminal SAM e um domínio contendo histidina e ácido aspártico (HD). O domínio SAM é envolvido em interações do tipo proteína-proteína e proteína-DNA/RNA. Proteínas com o domínio HD fazem parte de uma superfamília de fosfohidrolases comumente envolvidas no metabolismo de ácidos nucléicos. SAMHD1 tem a função de diminuir o pool de dNTPs intracelular, e mutações no gene de SAMHD1 está associada a Síndrome de Aicardi-Goutières (AGS). Nesse trabalho, avaliamos a especificidade de anticorpos comerciais anti-SAMHD1 em diferentes linhagens celulares, determinamos sua localização subcelular em resposta ao dano no DNA induzido por camptotecina (CPT) que induz duplas quebras na fita de DNA (DSBs - DoubleStrand Breaks). Por último, investigamos a possibilidade de existência de uma forma alternativa truncada endógena de SAMHD1. Vimos que o anticorpo anti-SAMHD1 monoclonal possui reatividade cruzada com uma proteína de aproximadamente $50 \mathrm{kDa}$, de função ainda desconhecida, enquanto que o anticorpo policlonal reconhece especificamente uma banda de massa molecular correspondente a SAMHD1. Além disso, identificamos que a hiperexpressão de SAMHD1 produz uma forma truncada SAMHD1(ATG2) sem os 114 primeiros aminoácidos, incluindo o domínio SAM. Esta forma foi produzida graças a um códon de início alternativo localizado a 345 nucleotídeos upstream do ATG1, do gene SAMHD1. Por fim, concluímos que SAMHD1 ativa a resposta ao dano, porém não é recrutada para o foci nuclear, diferente do que foi recentemente publicado na literatura.

Palavras chave: SAMHD1, Início alternativo de tradução, DSBs 


\section{ABSTRACT}

\section{Biochemical and subcellular characterization of SAMHD1 protein}

Medeiros, A. C., 2019.

Tese de doutorado 93p. Programa de Pós-graduação em Bioquímica da FMRP/USP.

SAMHD1 is a 626 amino acid protein in an N-terminal SAM motif and a domain containing histidine and aspartic acid (HD). The SAM domain is involved in protein-protein and proteinDNA / RNA interactions. Proteins with the HD domain are part of a superfamily of phosphohydrolases commonly involved in the metabolism of nucleic acids. SAMHD1 has the function of decreasing the pool of intracellular dNTPs, and mutations in the SAMHD1 gene are associated with Aicardi-Goutières Syndrome (AGS). In this work, we evaluated the specificity of commercial anti-SAMHD1 antibodies in different cell lines, determined their subcellular location in response to DNA damage induced by camptothecin (CPT) that induces double strand breaks (DSBs). Finally, we investigated the possibility of an endogenous truncated alternative form of SAMHD1. We have seen that the anti-SAMHD1 monoclonal antibody has cross-reactivity with a protein of approximately $50 \mathrm{kDa}$, of yet unknown function, whereas the polyclonal antibody specifically recognizes a band of molecular mass corresponding to SAMHD1. In addition, we have identified that the overexpression of SAMHD1 produces a truncated form SAMHD1 (ATG2) without the first 114 amino acids, including the SAM domain. This form was produced thanks to an alternative start codon located at 345 nucleotides upstream of the ATG1, SAMHD1 gene. Finally, we conclude that SAMHD1 activates the response to the damage, but it is not recruited to the nuclear foci, different from what has recently been published in the literature.

Key words: SAMHD1, alternative translation start, DSBs 


\section{LISTA DE ABREVIAÇÕES}

ActD - Actinomicina D

AGS - Síndrome Aicardi-Goutières

CPT - Camptotecina

dNTPs - desoxinucleotideo trifosfatase

DMP - Dimethylpimelimidate

DSB - Double-Strand Breaks

FANDS - FBXO25- associated nuclear domains

FBP - F-box protein

HA - Haemaglutinin peptide

HEK - Human embryonic kidney cells

HR - Recombinação Homóloga

PML - Promyelocytic leukemia protein

SCF1 - SKP1, CUL1, F-box protein

SUP - Sistema ubiquitina-proteassoma

TIS -Translation Initiation Site 


\section{Introdusãa}




\section{Introdução}

\subsection{FBXO25 e SAMHD1}

A proteína $\mathrm{FBXO25}$ é uma das 70 proteínas do tipo F-box (FBP) que possuem o domínio F-box de interação com SKP-1 e que atuam como fatores de especificidade para a família mais estudada de E3 ubiquitina-ligases humanas, as do tipo RING (Really Interesting New Gene-Box 1) ${ }^{1}$. Esta classe de E3-ligases são complexos oligoméricos denominados SCF1, compostos por SKP-1, CULLIN-1, ROC-1 e uma FBP, que estão envolvidos na ubiquitinação de proteínas para degradação via Sistema Ubiquitina Proteassoma (SUP) ou regulação funcional do substrato. Desta forma, a proteína FBXO25 é um componente de uma E3-ligase do tipo SCF1 capaz de formar um complexo $\mathrm{SCF}^{\mathrm{FBXO25}}$ estável e ativo em experimentos de ubiquitinação in vitro ${ }^{2,3}$. Ela foi descrita pela primeira vez in silico em $1999^{4,5}$, e é alvo de estudos em nosso grupo.

Em trabalhos anteriores, nosso grupo identificou que FBXO25 encontra-se no núcleo sob a forma de "dots", e parecem estar associados à estrutura da cromatina estando presentes apenas na fase G1/telófase do ciclo celular. Após estudos de co-localização com proteínas marcadoras de estruturas subnucleares conhecidas (por exemplo, Speckles, PML, Cajal etc..) verificamos se tratarem de novas estruturas subnucleares que foram denominadas "FANDs" (FBXO25 Associated Nuclear Domains) ${ }^{6}$. Trata-se do primeiro e único corpo nuclear composto de proteínas do tipo F-box caracterizado até o momento e o laboratório tem procurado estudar outras proteínas associadas aos FANDs.

Em busca de informações funcionais de proteínas associadas a FBXO25, foram utilizados arrays de proteínas humanas ou Protoarrays ${ }^{\circledR}$. É uma importante ferramenta por permitir o estudo de forma simultânea de milhares de proteínas ao mesmo tempo. 
Dr Heng Zhu em 2001 apresentou tal metodologia, em que cerca de 90\% do proteoma de levedura foi imobilizado em duplicata de forma direcional (via proteína de fusão GST) 5800 ORFs purificadas em uma lâmina de vidro ${ }^{7}$.

Diversos trabalhos vêm utilizando os arrays de proteínas para identificação de substratos de E3-ligases de mamíferos ${ }^{8,9,10}$. Os Protoarrays contêm 21.120 proteínas humanas imobilizadas, sendo 8.295 proteínas únicas e 2.122 controles, sendo todas em duplicata.

Nosso laboratório fez a primeira descrição do uso dessa estratégia para uma enzima E3 ligase oligomérica tipo SCF. Demonstramos que FBXO25 interage, ubiquitina e medeia a degradação proteassomal do fator de transcrição ELK-1 envolvido na indução gênica inicial imediata. Observou-se também que os efeitos celulares dessa atividade de FBXO25 promoveram a redução da ativação dos genes alvos de ELK-1 c-FOS e EGR1 em células HEK 293T estimuladas pelo mitógeno PMA ${ }^{11}$.

Outras proteínas também foram identificadas nesse screening, dentre elas, a

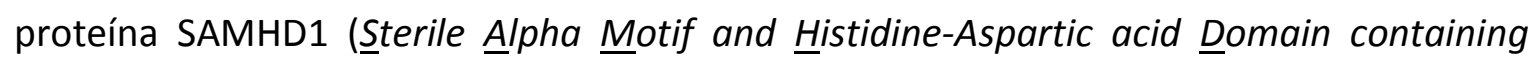
protein 1), que é descrita como alvo do SUP.

SAMHD1 foi originalmente descoberta em células dendríticas humanas como proteína homóloga a uma proteína de camundongo denominada proteína induzida por IFN- $\gamma$ derivada de células dendríticas (DCIP), sugerindo uma função na resposta imune inata ${ }^{12}$. SAMHD1 tem atividade antiviral dependente do GTP reduzindo a concentração de dNTPs abaixo de um limiar utilizável para a replicação eficiente do vírus da imunodeficiência humana tipo 1 (HIV-1) ${ }^{13}$. Análises bioquímicas subsequentes, revelaram atividade catalítica hidrolásica de enzima, dependência de íon metálico 
divalente e ativação por nucleotídeos de guanosina ${ }^{14}$. Recentemente, uma atividade ribonuclease é discutida, controversamente, como uma segunda atividade antiviral enzimática ${ }^{15}$.

SAMHD1 é uma proteína de 626 aminoácidos que possui um motivo N-terminal SAM e um domínio contendo histidina e ácido aspártico (HD) na porção central de sua estrutura. O domínio SAM é comumente envolvido em interações do tipo proteínaproteína e proteína-DNA/RNA ${ }^{16}$. O sinal de localização nuclear que precede o domínio SAM, confere a localização nuclear observada em vários estudos ${ }^{17,18}$. O domínio HD define-se pelo seu quarteto característico de metal que coordena resíduos de histidina e ácido aspártico dentro do sítio ativo da enzima. Proteínas que contem o domínio HD representam uma superfamília de fosfohidrolases comumente envolvidas no metabolismo de ácidos nucléicos ${ }^{19}$. É no domínio HD também onde se encontram os sítios ativos responsáveis pela atividade dNTPase, sítios regulatórios e também é requisito para interface da oligomerização de SAMHD1 ${ }^{20}$. A região C-terminal de SAMHD1 consiste de uma região distinta importante para a estabilização do estado oligomérico da enzima e interação com ácidos nucléicos ${ }^{21}$.

SAMHD1 foi alvo de estudo do nosso grupo durante o projeto de pós-doutorado da Dra Claúdia Sossai, em que ela realizou estudos para validar a interação entre FBXO25 e SAMHD1. Para isso, foi feita a imunopreciptação de SAMHD1 de células HEK 293T e por western blotting foi confirmada a interação dessa proteína com a FBXO25. Demonstrouse que SAMHD1 interagiu tanto com FBXO25WT quanto com a FBXO25 $\triangle \mathrm{F}$ (mutante Fbox que se liga ao seu substrato, mas não a proteína SKP-1, portanto incapaz de formar o complexo SCF ativo) (Figura 1B). 
A proteína FBXO25 é caracterizada por se acumular no núcleo celular nos FANDs, que são altamente responsivos ao estado transcrional ${ }^{6}$. Já SAMHD1, devido ao seu domínio SAM, se liga a ácidos nucléicos e está comumente presente em proteínas envolvidas na transcrição ${ }^{22}$. Logo, para investigar a interação e redistribuição de FBXO25 e SAMHD1, foi realizado o tratamento com o inibidor transcricional Actinomicina D (ActD). Dessa forma, foi demonstrado por microscopia confocal em células HEK 293T, que os dots de SAMHD1 e FBXO25 se colocalizam na porção nucleoplasmática (Figura 1A). Porém quando as células foram tratadas com $5 \mu \mathrm{g} / \mathrm{mL}$ de ActD por 2 horas, tanto SAMHD1 quanto FBXO25 foram redistribuídas no nucleoplasma, perdendo suas estruturas em forma de dots e diminuindo a colocalização dessas duas proteínas. Esses resultados nos levaram a estudar e caracterizar a interação de FBXO25 com a proteína SAMHD1. 
A)

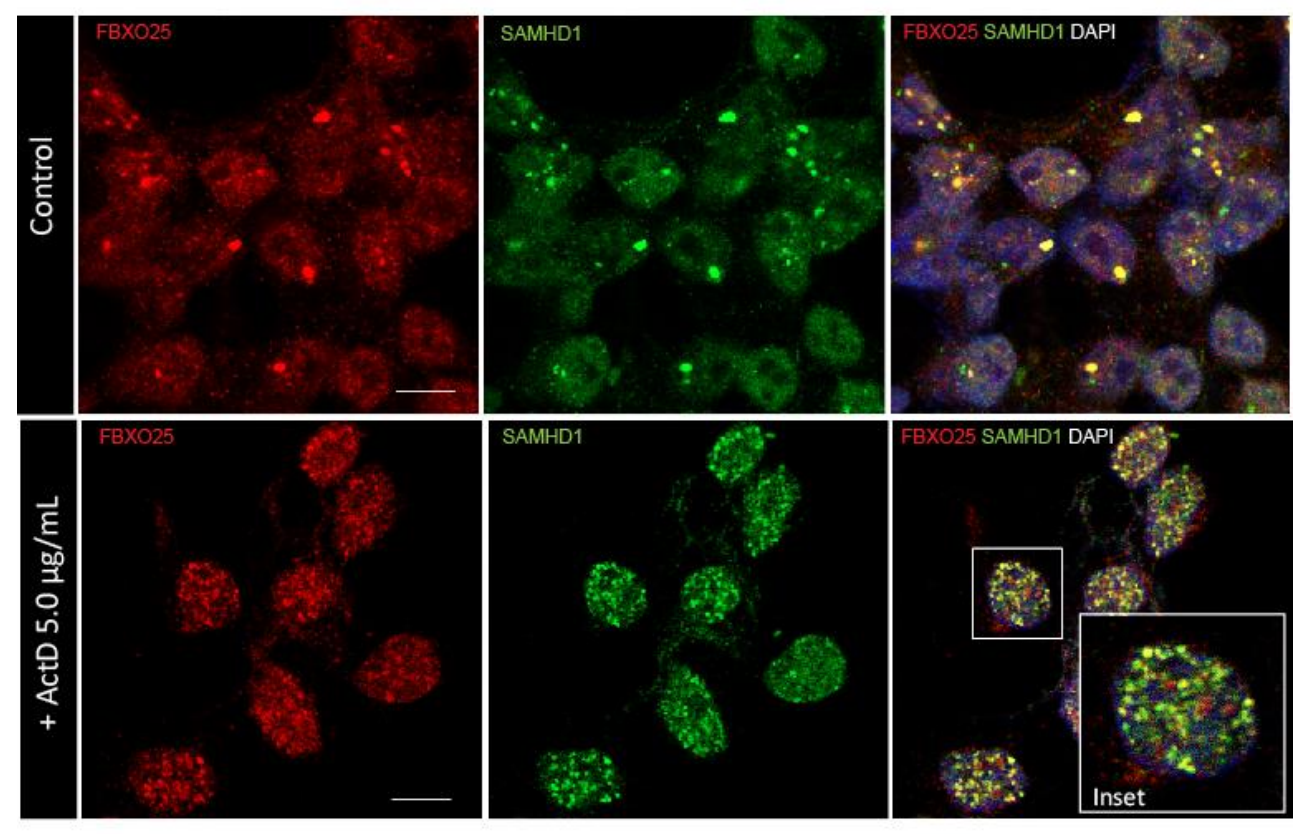

B)

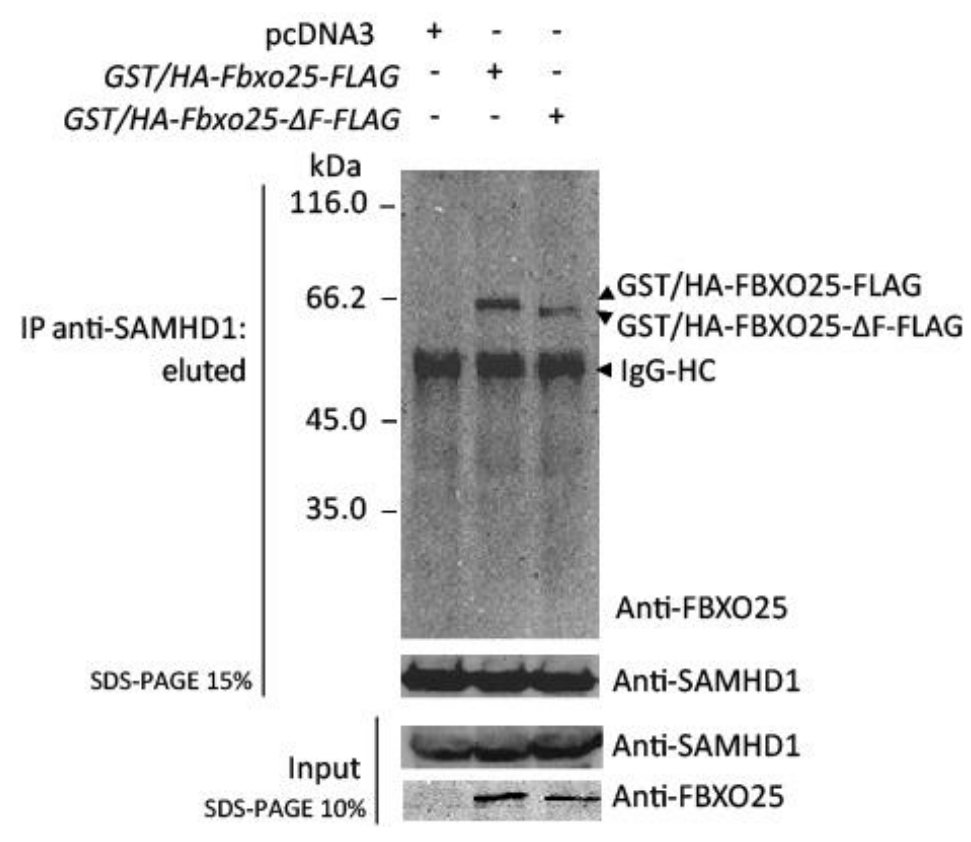

Figura 1: Estrutura subnuclear rica em SAMHD1 co-localiza com FBXO25 e ambas são alteradas pelo tratamento com ActD. A) Análise confocal de dupla marcação utilizando anticorpos antiSAMHD1 monoclonal e anti-FBXO25 em células HEK 293T transfectadas com GST-FBXO25-FLAG tratadas com ActD. DAPI - para marcação de núcleo e nucléolo. Barra - $5 \mu \mathrm{m}$. B) Células HEK 293T foram transfectadas com pcDNA3 (vetor vazio - controle), GST-FBXO25WT-FLAG ou GST-FBXO25 $\Delta F-$ FLAG. Após 48 horas, os lisados foram submetidos a imunoprecipitação com o anticorpo antiSAMHD1. Em seguida, foi realizado um western blotting marcando com o anti-FBXO25. As análises mostraram que SAMHD1 endógena interage tanto com FBXO25WT quanto com FBXO25 $\triangle \mathrm{F}$. IgG-HC: cadeia pesada do anticorpo. 


\subsection{SAMHD1 e Resposta Imune Antiviral}

Uma das principais funções de SAMHD1 na resposta imune inata consiste na diminuição do pool de dNTPs intracelular, como no caso do vírus HIV-1 em que SAMHD1 bloqueia a infecção em células não-cíclicas como macrófagos, células dendríticas e células T CD4+ quiescentes ${ }^{23}$, reduzindo a transcrição reversa e a síntese de cDNA do HIV $-1^{24}$.

Como uma proteína multifuncional, SAMHD1 tem funções importantes na progressão do ciclo celular ${ }^{25,26}$, desenvolvimento de câncer ${ }^{27}$ e imunidade adaptativa ${ }^{28}$. Algumas retroviroses como o HIV-2 e o vírus da imunodeficiência símia (SIV) contém uma proteína viral chamada proteína X (Vpx) que antagoniza a função antiviral de SAMHD1, por recrutar SAMHD1 ao complexo E3 ubiquitina ligase CRL4 ${ }^{\text {DCAF1 } 29}$. Esse recrutamento resulta em uma degradação dependente do proteassoma, através do qual o Vpx alivia a mediação de SAMHD1 na restrição da replicação lentiviral em células mielóides ${ }^{30,31}$.

Mutações em SAMHD1 causam a Síndrome Aicardi-Goutières (AGS), um grave distúrbio genético neurodegenerativo que mimetiza a infecção viral congênita ${ }^{32}$ caracterizada por ativação imunológica inadequada e grande secreção de interferon alfa 33-35. Da mesma forma, mutações no gene da exonuclease TREX1 e nos três genes que codificam a endonuclease RNase $\mathrm{H} 2$ podem causar AGS, ligando o metabolismo de ácidos nucléicos com este distúrbio autoimune ${ }^{36-38}$. TREX1 é a principal 3'-exonuclease que degrada DNA celular de fita simples e dupla ${ }^{39-45}$. Em células infectadas pelo HIV-1, o TREX1 degrada transcritos não-produtivos evitando cDNA viral em excesso, impedindo a ativação da resposta imune inata ${ }^{46,47}$. A RNase $\mathrm{H} 2$ reconhece e cliva ribonucleotídeos presentes em duplex de RNA / DNA ${ }^{48,49}$ e o silenciamento da RNAse H2 dificulta a 
replicação do HIV $^{50}$. Isso sugere que SAMHD1 e outras proteínas associadas à AGS, estão envolvidas com a regulação da resposta imune inata ${ }^{51}$.

\subsection{Atividade de reparo de DNA de SAMHD1}

SAMHD1 promove a integridade do genoma, por manter baixo os pools de dNTPS na célula, por meio de sua atividade dNTPase ${ }^{52-55}$. No entanto, o aumento espontâneo de dano no DNA e dos pools de dNTPs foi observado em pacientes com AGS ${ }^{54}$. Além disso, mutações heterozigóticas associadas ao câncer colorretal, impedem a atividade dNTPase de SAMHD1. Assim, elevados índices de dNTPs combinados com uma falha no reparo do DNA, aumentam o índice de mutações, sugerindo cânceres associados a SAMHD1 ${ }^{26}$.

Estudos mostraram que SAMHD1 é recrutada para locais de dano em resposta a agentes como camptothecina (CPT) conhecidos por causarem duplas quebras na fita de DNA (DSBs - Double-Strand Breaks), e que estava envolvida na resposta a DSBs por interagir com proteínas específicas de reparo ${ }^{55}$.

Em um trabalho mais recente, foi demonstrado que SAMHD1 promove o reparo de DSBs predominantemente na fase $S$ do ciclo celular, fase em que o reparo por recombinação homóloga (HR) acontece ${ }^{56}$. Além disso, SAMHD1 colocalizou-se com $\mathrm{H}$ 2AX, marcador de DSBs, e com RAD51, marcador para HR. A HR tem início com a ressecção do DNA e tem a participação de duas endonucleases, a CtBP (proteína de ligação C-terminal) que interage com o complexo MRN (MRE11-RAD50-NBS1) ${ }^{62-67}$, se transformando na proteína de interação (CtIP) que realiza o processamento das 
extremidades $5^{\prime}$ das DSBs ${ }^{57-61}$ e geram um curto overhang na extremidade $3^{\prime}$ do DNA de fita simples (ssDNA), que será estendido pelas nucleases EXO1 ou DNA2 junto com BLM ou WRN helicase ${ }^{68-73}$. Esse 3'ssDNA overhang é ligado por RPA, que é então deslocado por RAD51, para formar RAD51-ssDNA, um microfilamento de nucleoproteínas, que com ajuda de proteínas mediadoras, incluindo BRCA2, medeiam a $\mathrm{HR}^{74}$ (Figura 2). RPA-ssDNA também recruta ATRIP para ativar ATR kinase checkpoint ${ }^{75}$. Sendo assim, a ressecção do DNA é um determinante crítico para o reparo do DNA e ativação de checkpoints.

Nesse mesmo estudo, foi mostrado que SAMHD1 promove a HR e ativação de ATR, por promover a ressecção do DNA, de maneira independente de sua atividade de dNTPase bem estabelecida. SAMHD1 facilita o recrutamento de CtIP, que por sua vez coopera com a MRN para promover a resseç̧ão final do DNA demonstrando que SAMHD1 tem um papel direto na manutenção do genoma independente do seu papel na regulação do pool de dNTPs ${ }^{56}$. 


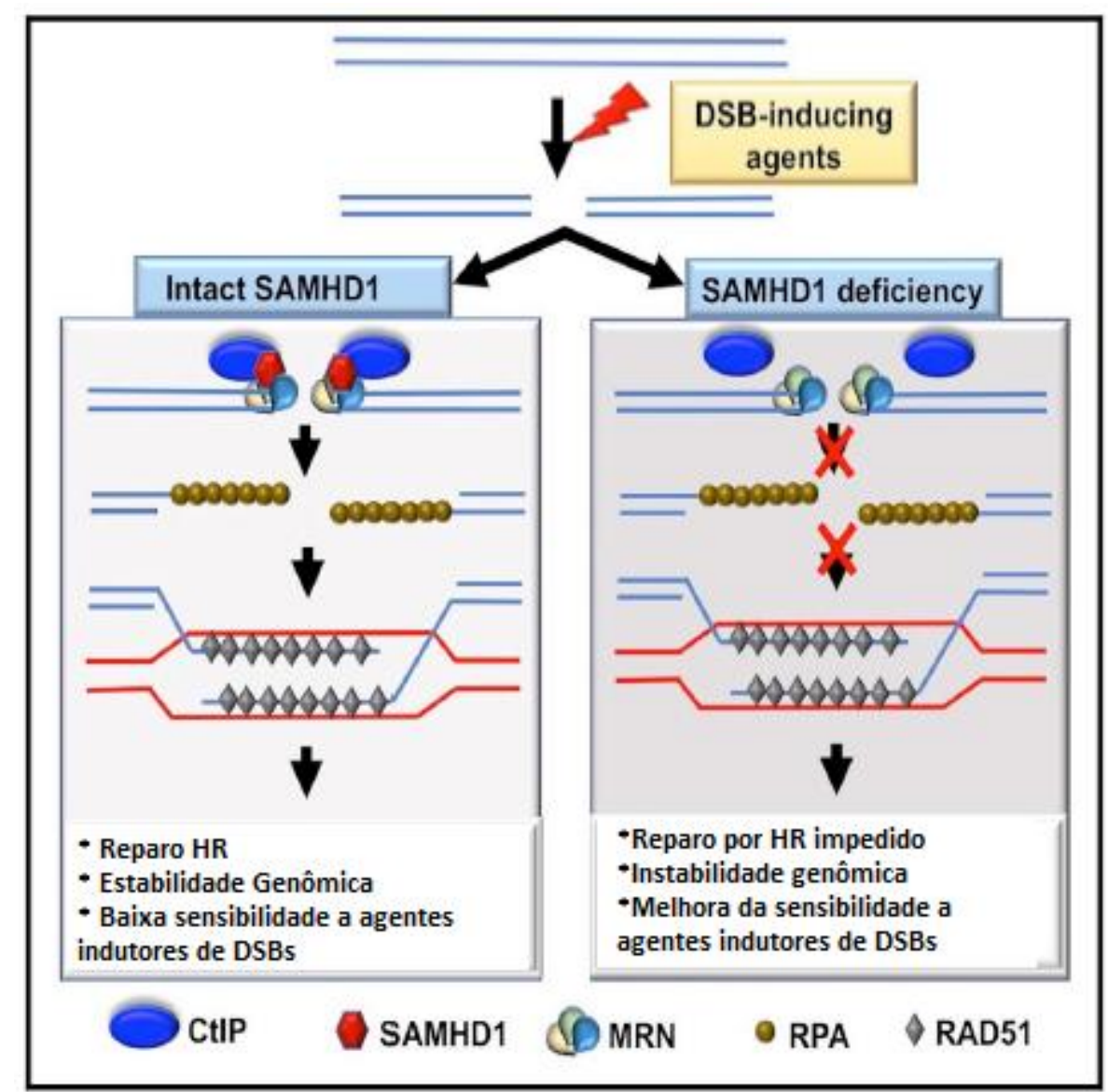

Figura 2: SAMHD1 atua no reparo de DNA via recombinação homóloga (HR). SAMHD1 promove o reparo de DSBs por HR independente de sua atividade de dNTPase bem estabelecida. SAMHD1 facilita o recrutamento de CtIP, que por sua vez coopera com a MRN para promover a ressecção final do DNA. Quando há deficiência de SAMHD1, o reparo por HR é impedido e a estabilidade genômica comprometida (Modificado: Daddacha et al., 2017). 
Iniciamos nossos estudos a partir da interação da proteína FBXO25 e SAMHD1 utilizando o anticorpo monoclonal Origene Technologies e vimos que SAMHD1 apresentava marcação nuclear dot-like, que colocalizavam com FBXO25. No entanto, por western blotting, esse mesmo anticorpo marcava, além da banda de massa molecular correspondente a SAMHD1, outra banda de massa molecular de aproximadamente 50 kDa (p50). Para confirmar esses dados e estudar a possibilidade de um inicio alternativo de tradução, adquirimos o anticorpo policlonal Proteintech Group, que não apresentou marcação dot-like, nem tampouco reconhecia a p50, o que nos levou a questionar a especificidade do anticorpo monoclonal. No entanto, Daddacha et al, 2017, utilizou esse mesmo anticorpo monoclonal para descrever a redistribuição de SAMHD1 para os foci nucleares, em resposta a DSBs. No presente estudo estabelecemos estratégias para caracterizar a localização intracelular de SAMHD1, assim como determinar sua distribuição em resposta ao dano no DNA e investigar a presença de formas endógenas truncadas da proteína SAMHD1. 
Objetivas 


\section{Objetivo Geral}

Caracterizar a localização intracelular de SAMHD1 em diferentes linhagens celulares em resposta ao dano no DNA e investigar a presença de formas endógenas truncadas desta proteína.

\subsection{Objetivos específicos}

- Analisar a especificidade dos anticorpos comerciais anti-SAMHD1, monoclonal

Origene Technologies e o policlonal Proteintech Group, em diferentes linhagens celulares não mielóides;

- Avaliar a existência de um sítio de início alternativo de tradução da proteína SAMHD1;

- Avaliar a localização celular de SAMHD1 e sua resposta ao dano no DNA induzido por CPT;

- Identificar as proteínas que possuem reatividade cruzada do anticorpo anti-SAMHD1 monoclonal. 
Metodologia 


\section{METODOLOGIA}

\subsection{Plasmídeos e anticorpos}

O plasmídeo que codifica o gene SAMHD1 humana (NM_015474) foi obtido da Origene Technologies (Rockville, MD). Os anticorpos monoclonais de camundongo antiGAPDH (clone 71.1, \#G8795), anti- $\beta$-Actina (clone AC74, \#A2228), anti- $\beta$-Tubulina (clone TUB 2.1, \#T4026), e anti-HA (clone HA-7, \#H3663) foram adquiridos da Sigma-Aldrich (St. Louis, MO). O anticorpo monoclonal de camundongo Anti-SAMHD1 (IgG2b; clone3F5, \#TA502024) contra proteína recombinante inteira, humana, foi adquirido da Origene Technologies (Rockville, MD). O anticorpo policlonal de coelho Anti-SAMHD1 (\#12586-1-AP) produzido contra os 314 aminoácidos da região N-terminal de hSAMHD1 foi adquirido do Grupo Proteintech (Chicago, IL). Os plasmídeos que expressam a construção HA-RRAGD, GSK3ß-HA e RAD51-HA foram gentilmente cedidos pelo Dr. Jung Min Han (Universidade Yonsei, Seoul, Córeia do Sul), Dr. Felipe Roberti Teixeira (Universidade Federal de São Carlos, São Carlos) e Dr. Francis Lanch (Universidade Rockefeler, Nova York, EUA), respectivamente.

\subsection{Subclonagem e mutagênese}

O gene SAMHD1 foi subclonado no plasmídeo pcDNA3.1 usando a construção da Origene como molde.

A reação de $P C R$ foi realizada utilizando primers com sítios de restrição para $E c o R I$ ou Xhol em suas respectivas extremidades $3^{\prime}$ e 5' (Tabela 1). Os produtos de PCR foram purificados e subclonados no vetor pcDNA3.1. O produto de PCR foi analisado em gel de agarose $1 \%$ através de eletroforese. Esse produto foi então purificado utilizando o QIAquick ${ }^{\circledast}$ Gel Extraction kit (QIAGEN) de acordo com as recomendações do fabricante e, em seguida, 
digerido com as enzimas de restrição. O produto de PCR e o vetor foram purificados utilizando o mesmo kit de purificação e em seguida, ligados utilizando T4 DNA ligase (Fermentas).

As transformações de bactérias contendo essas construções foram realizadas por heat shock, e as preparações plasmidiais em pequena escala (mini-preps) foram realizadas com o kit da QIAGEN Plasmid Purification(QIAGEN). As construções foram selecionadas a partir da análise de enzimas de restrição e os fragmentos analisados em gel de agarose $1 \%$.

O mutante no ATG2 [SAMHD1(AAG2)-HA] foi produzido por mutação sítio dirigida. Isso gerou uma mutação pontual, trocando o códon da Met 345 por uma lle. A reação de PCR foi realizada da seguinte forma: $98^{\circ} \mathrm{C}$ por 10 s, 18 ciclos de $95^{\circ} \mathrm{C}$ por $20 \mathrm{~s}, 68^{\circ} \mathrm{C}$ por $30 \mathrm{~s}$ e $72{ }^{\circ} \mathrm{C}$ por $110 \mathrm{~s}$, seguido por uma última extensão de 5 min a $72{ }^{\circ} \mathrm{C}$. O DNA parental foi digerido com a enzima Dpnl. Essa enzima é responsável pela degradação do DNA metilado (o da bactéria), deixando apenas o amplicon. Em seguida, as reações foram colocadas em estufa a $37^{\circ} \mathrm{C}$, overnight, por um período máximo de 18 horas.

As amostras de PCR foram analisadas em gel de agarose $1 \%$ para análise dos fragmentos gerados. Em seguida, bactérias competentes foram transformadas e as colônias submetidas ao procedimento de extração do DNA plasmidial em pequena escala (Mini-Preps QIAGEN). O DNA plasmidial purificado foi digerido com a enzima de restrição Pvull (Thermo Scientific) para análise do perfil dos mutantes gerados. Aquele com perfil de digestão diferente, comparado com o plasmídeo SAMHD1 WT, foi sequenciado pelo método de Sanger, para confirmação da mutação. 
Tabela 1- Sequência dos primers utilizados:

\begin{tabular}{|c|c|}
\hline Primers & Sequências $\left(5^{\prime} \rightarrow 3^{\prime}\right)$ \\
\hline SAMHD1-HA sense & CTACGGGAATTCATGCAGCGAGCCGATTCCGAGCAGC \\
\hline SAMHD1-HA antissense & $\begin{array}{l}\text { ACCGAGCTCGAGTCAAGCGTAATCTGGTACGTCGTATGGGTACATTGGGTC } \\
\text { AT CTTTAAAAAGCTGGACTCTGCTTTTG }\end{array}$ \\
\hline $\begin{array}{l}\text { SAMHD1(ATG2)-HA } \\
\text { sense }\end{array}$ & AGCTAGGAATTCATGAAGGTAATTAATGATCCTATCC \\
\hline $\begin{array}{l}\text { SAMHD1(ATG2)-HA } \\
\text { antissense }\end{array}$ & ACCGAGCTCGAGTCAAGCGTAATCTGGTACGT \\
\hline $\begin{array}{l}\text { SAMHD1(AAG2)-HA } \\
\text { sense }\end{array}$ & ATCCACGTTGATACAATCAAGGTAATTAATGATCC \\
\hline $\begin{array}{l}\text { SAMHD1(AAG2)-HA } \\
\text { antissense }\end{array}$ & GGATCATTAATTACCTTG ATTGTATCAACGTGGAT \\
\hline
\end{tabular}

\subsection{Knockout e knockdown de SAMHD1}

As células SAMHD1 knockout foram adquiridas da Horizon Discovery (Austria, \#HZGHC000813c007) baseado na linhagem celular humana quase haplóide HAP1 e no sistema de edição de genoma CRISPR/Cas9 como descrito por Zheng et al. ${ }^{76}$. Os clones de células únicas de HAP1 foram diluídos e isolados e os genótipos foram analisados por PCR e sequenciados usando os primers forward (5'-CTACCTCGGATGTTCTTCAGCAG-3') e reverso (5'-AATAGGCTGCCAATACTCCTTGG-3') para confirmação.

Para o knockdown de SAMHD1, utilizou-se uma mistura de quatro siRNA ONTARGETplus para SAMHD1 humana, de acordo com as especificações do fabricante (Dharmacon ${ }^{\mathrm{TM}}$, Lafayette, CO). Os siRNAs alvo para SAMHD1 foram direcionados para as sequências descritas na tabela 2, adquiridas da Dharmacon $^{\mathrm{TM}}$ (Lafayette, CO). As transfecções foram carreadas utilizando o reagente de transfecção DharmaFECT ${ }^{\oplus}$ 
(Dharmacon $^{\mathrm{TM}}$, Lafayette, CO) de acordo com as especificações do fabricante (Thermo Scientific) por 48 horas.

Tabela 2- Sequência dos siRNAs utilizados

\begin{tabular}{ll}
\hline siRNA & Sequências \\
\hline $\mathrm{J}-013950-09$ & GACAAUGAGUUGCGUAUUU \\
$\mathrm{J}-013950-10$ & CAUGUUUGAUGGACGAUUU \\
$\mathrm{J}-013950-11$ & AAGUAUUGCUAGACGUGAA \\
$\mathrm{J}-013950-12$ & UUAGUUAUAUCCAGCGAUU \\
\hline
\end{tabular}

\section{4- Células: cultivo e transfecção transiente}

Células HEK 293T (ATCC, CRL-11268), e Neuro2A (ATCC, CCL-131) foram crescidas em meio DMEN (Invitrogen Life Technologies, Carlsbad, CA). Enquanto células Namalwa (ATCC, CRL-1432) e Jurkat foram crescidas em meio RPMI 1640 (Invitrogen Life Technologies, Carlsbad, CA). A linhagem celular quase haplóide HAP1 (Haplogen Genomics, Austria) foi mantida em meio IMDM (Invitrogen Life Technologies, Carlsbad, CA). Todos os meios foram suplementados com $10 \%$ SFB (soro fetal bovino, Invitrogen, Carlbad, CA) e $5 \% \mathrm{CO}_{2}$. As transfecções foram carreadas utilizando Polietilenamina (PEI, linear) $1 \mu \mathrm{g} / \mu \mathrm{L}$ em Tris-HCL pH 7.2, por $48 \mathrm{~h}$. As células HeLa foram tratadas com $2 \mu \mathrm{M}$ de Camptotecina (CPT, SigmaAldrich, St. Louis, MO) por 4hr e processadas para imunofluorescência.

\subsection{Microscopia confocal de Fluorescência}

Para imunofluorescência direta, células HAP1/HeLa foram crescidas sobre lamínulas de vidro com meio IMDM ou DMEM, respectivamente, suplementado com $10 \mu \mathrm{g} / \mathrm{mL}$ de estreptomicina e $10 \mathrm{U} / \mathrm{mL}$ de penicilina. As células foram fixadas e permeabilizadas por 10 
minutos TA com PBS contendo 2\% de paraformaldeído (Eletron Microscopy Science, \#15710) e $0.3 \%$ de Triton X-100. Em seguida, as lamínulas foram bloqueadas com PBS/2\% BSA. As incubações com os anticorpos (anti-SAMHD1 monoclonal Origene Technologies 1:1000, e o anti-SAMHD1 policlonal Proteintech Group 1:200) foram feitas por $1 \mathrm{~h}$ a T. A. em PBS/2\% BSA seguido pela incubação com os anticorpos secundários Alexa 488 ou Alexa 594 (1:600), por 30 minutos. As lamínulas foram montadas com o meio de montagem Prolong antifade contendo DAPI (Invitrogen Life Technologies, Carlsbad, CA). As amostras foram analisadas em microscópio confocal Leica TCS SP5 laser scanning (Leica Microsystems, Germany).

\subsection{Western blotting}

Para a preparação dos lisados, 5 × $10^{6}$ células foram lavadas com PBS gelado, e então foi adicionado $400 \mu \mathrm{L}$ tampão de lise $(25 \mathrm{mM}$ Tris- $\mathrm{HCl}, \mathrm{pH}$ 7.4, $225 \mathrm{mM} \mathrm{KCl}$, and 1\% Nonidet P-40), mais uma mistura de inibidores de proteases (Sigma-Aldrich) e fosfatases ( NaF 10 $\mathrm{mM}, \mathrm{Na}_{3} \mathrm{VO}_{4}$ 1mM; Sigma-Aldrich). As amostras foram então vortexadas e subsequentemente incubadas no gelo por 30 minutos. Os lisados foram clarificados por centrifugação $20000 \times$ g por $20 \mathrm{~min}$, a $4^{\circ} \mathrm{C}$. A concentração de proteínas no lisado celular foi determinada usando o Reagente de Bradford (Sigma-Aldrich, St. Louis, MO). Assim, sessenta microgramas de proteína do lisado foram submetidos a eletroforese em gel poliacrilamida contendo SDS (SDS-PAGE), transferido para uma membrana de nitrocelulose e incubado overnight com os anticorpos primários. As membranas foram lavadas com TBST (Tampão Tris Salina com 0,1\% de detergente Tween20), incubadas com anticorpos secundários conjugados a peroxidase e lavados de novo com TBST. As bandas de proteína foram 
visualizadas pelo método de quimioluminescência com ECL (Santa Cruz Biotechnology) utilizando o programa ImageQuant (GE).

\subsection{Ligação do anticorpo SAMHD1 a resina conjugada a uma mistura de} proteínas A e G usando Dimethylpimelimidate (DMP), para imunopurificação

Para purificação de SAMHD1 de células HEK 293T sem a presença de anticorpos utilizados na imunoprecipitação, conjugamos covalentemente o anticorpo anti-SAMHD1 à resina de agarose.

- Imobilização do anticorpo anti-SAMHD1 à resina de agarose-proteína A/G: Em um tubo, foi adicionado $20 \mu \mathrm{g}$ do anticorpo anti-SAMHD1 monoclonal (Origene) a $30 \mu \mathrm{L}$ de resina de agarose-proteína A/G, e em outro tubo, foi adicionado $20 \mu g$ de IgG de camundongo como controle de acoplamento. A mistura foi deixada sob agitação overnight a $4^{\circ} \mathrm{C}$. Em seguida, as resina foram lavadas três vezes com $1 \mathrm{~mL}$ tampão de ligação (borato de sódio 0,2M, pH 9).

- Crosslinking: O reagente de crosslinking foi preparado momentos antes do uso, devido sua instabilidade. Foi preparada uma solução de $20 \mathrm{mM}$ de DMP (dimethylpimelimidate, ThermoFisher ), dissolvido em tampão de ligação. $1 \mathrm{~mL}$ dessa solução foi imediatamente adicionada a cada tubo. A mistura foi deixada sob agitação T. A. por 40 minutos. Após esse período, a resina foi lavada e ressuspendida em reagente de "extinção" (0,2M de etanolamina em 50 mM de bicarbonato de 
amônia). As resinas ficaram incubadas por 2 horas T.A. com o reagente de extinção, para promover a remoção/extinção de todo resíduo de DMP que não foi ligado.

Para remoção das IgGs que não foram acopladas, foi feita a lavagem das resinas com tampão ácido $(0,58 \%$ v/v de ácido acético e $150 \mathrm{mM}$ de $\mathrm{NaCl})$, por 3x1 mL. Em seguida, as resinas foram lavadas $3 x$ com $1 \mathrm{~mL}$ de PBS $1 x$, gelado. Foi adicionado 2 gotas de tampão Tris- $\mathrm{HCl}$ pH 12, para neutralização do pH.

Para checar a eficiência de imobilização do anticorpo à resina, uma alíquota (5 $\mu \mathrm{L}$ ) das amostras antes e depois do crosslinking, e depois da lavagem com tampão ácido, foram eluídas pela adição de tampão de amostra $2 x(1 \mathrm{M}$ Tris- $\mathrm{HCl}$ pH 6,8; $5 \% \beta-$ mercaptanol; 2\% SDS; 0,004\% Azul de bromofenol e Glicerol 10\%). As amostras foram fervidas por 5 minutos a $100{ }^{\circ} \mathrm{C}$ e aplicadas em gel de poliacrilamida. Em seguida, as proteínas do gel foram transferidas para membrana de nitrocelulose. A membrana foi então incubada com anticorpo secundário de camundongo e de coelho por 1h T.A., e revelada pelo método de quimioluminescência.

- Imunopurificação: Os lisados foram preparados como descrito no item 3.6. Antes da aplicação do lisado às resinas acopladas, foi realizado o pre-clearing, que consiste na adição do lisado à resina $A / G$ não acoplada por 30 minutos. Após essa incubação, a mistura foi centrifugada e o sobrenadante reservado para IP. $1 \mathrm{~mL}$ de lisado foi adicionado a aproximadamente $25 \mu \mathrm{L}$ de resina acoplada. A mistura foi deixada sob agitação overnight, $4^{\circ} \mathrm{C}$. Após esse período, a resina foi centrifugada e o sobrenadante descartado. A resina foi lavada 7x com o tampão de lise (150mM NaCl, 50mM Tris, 10mM EGTA, 0.2\% NP40). Após a última lavagem, foi adicionado $40 \mu \mathrm{L}$ de Glicina 100 mM pH 2, por 3 horas, para completa eluição do complexo. O eluído foi analisado por western blotting. 


\subsection{Identificação de reatividade cruzada do anti-SAMHD1 monoclonal utilizando o} Protoarray $^{\circledast}$

Para determinar a especificidade de ligação do anticorpo anti SAMHD1 Origene frente a outras proteínas, nós utilizamos o Protoarray ${ }^{\circledR}$ v5.0 (Invitrogen Life Technologies, Carlsbad, CA). Os procedimentos com os Protoarrays $^{\circledR}$ seguiram as instruções do fabricante. Nesse ensaio, utilizamos 2 lâminas de Protoarray ${ }^{\circledR}$ : uma foi incubada com o anti-SAMHD1 Origene, e a outra foi incubada apenas com o anticorpo secundário, como controle negativo do experimento.

As lâminas do Protoarray foram incubadas com tampão de bloqueio (50 mM de HEPES, $200 \mathrm{mM}$ de $\mathrm{NaCl}, 0,08 \%$ de Triton $\mathrm{X}-100,25 \%$ glicerol, $20 \mathrm{mM}$ de glutationa reduzida, $1 \mathrm{mM}$ de ditiotreitol (DTT), e 1\% de albumina de soro bovino (BSA) (Invitrogen) durante $1 \mathrm{~h}$ a $4{ }^{\circ} \mathrm{C}$ em agitação $50 \mathrm{rpm}$. Após esse período, a solução de bloqueio foi removida e em seguida foi adicionada uma solução do anti SAMHD1 0,5 $\mu \mathrm{g} / \mathrm{mL}$, em solução de PBS 1x. A mistura foi deixada sob agitação por $2 \mathrm{~h}$, $4{ }^{\circ} \mathrm{C}$. O anticorpo primário foi decantado, e as lâminas foram lavadas $3 \times 10 \mathrm{~min}$ com o tampão de lavagem (PBS 10X, Tween 20 10\% e sintetic block) Por fim, as lâminas foram então incubadas com 1,0 $\mu \mathrm{g} / \mu \mathrm{L}$ de anti-mouse AlexaFluor 647 durante 90 min a $4{ }^{\circ} \mathrm{C}$, com agitação de $50 \mathrm{rpm}$. Em seguida, elas foram lavadas cinco vezes com tampão de lavagem e uma vez com água destilada. As lâminas foram secas por centrifugação a 200 x g por 2 minutos, protegidas da luz. As lâminas foram escaneadas em GeneScan5000B (Lab. Prof. Dr. Gustavo H. Goldman/Ciências Farmacêuticas/FCFRP-USP) utilizando o software GenePix. 
Os Protoarrays foram digitalizados, e a aquisição dos dados e subtração do background local foram adquiridos com software GenePix 4.1 (Molecular Devices) e os dados analisados em ProspectorAnalyser 5.1 (Invitrogen). As proteínas foram consideradas somente se todas as replicatas internas fossem consistentemente detectadas pelo Coeficiente de Variância (CV) de $50 \%$. Os spots foram considerados hits se possuíssem o Z-factor $>0,45$. Isso significa que o sinal apresentado leva em consideração a variação associada às características do controle e da amostra para medir a qualidade do ensaio. 
Resultados 


\section{4- RESULTADOS}

\subsection{Especificidade do anticorpo anti-SAMHD1 (Origene Technologies) em} diferentes linhagens celulares não mielóides

Para avaliarmos a expressão de SAMHD1 em diferentes linhagens celulares não relacionadas a estudos de infecção viral, utilizamos células HEK 293T (transfectadas ou não com o plasmídeo SAMHD1 sem tag), Namalwa (linfoma de Burkitt - células linfoblastóide B) e Neuro 2A (tumor espontâneo de cérebro de camundongo albino). Essas células foram lisadas em tampão de lise e os sobrenadantes foram submetidos à análise por western blotting. Inicialmente, utilizamos apenas o anticorpo anti-SAMHD1 monoclonal produzido contra a proteína SAMHD1 inteira (Origene Technologies), e observamos que anticorpo monoclonal reconhece três diferentes bandas em HEK 293T não transfectada, uma com massa molecular maior que 66 kDa (1), outra com massa molecular próximo a 66 kDa (2) e uma com massa molecular menor que 66kDa (3. Após a transfecção, verificamos mais uma banda um pouco acima da banda 3. Nas demais células testadas, o anti-SAMHD1 também reconheceu as três bandas observadas (Figura 3).

Esses dados nos levaram a investigar se as bandas seriam provenientes de um sítio alternativo de tradução de SAMHD1. 


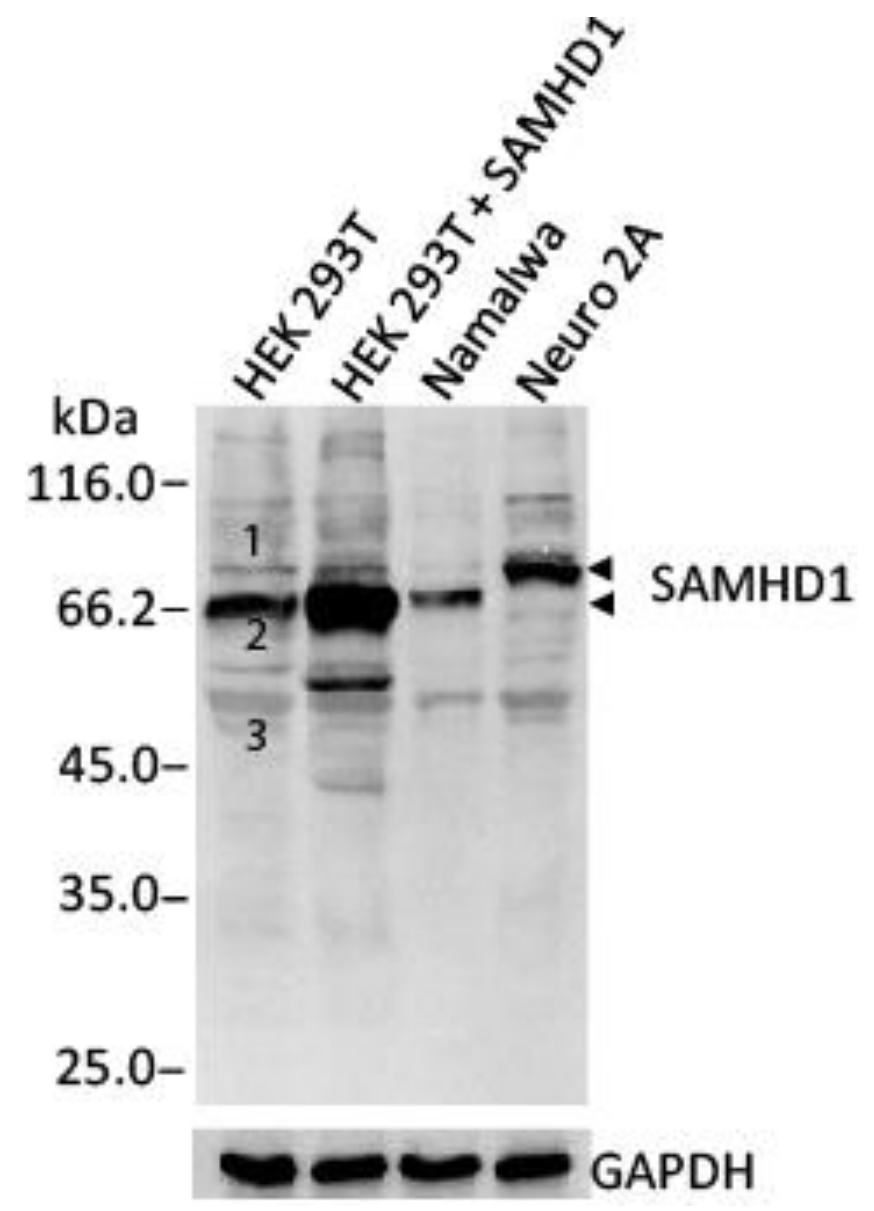

Figura 3: Expressão de SAMHD1 em diferentes tipos celulares. Lisados de células HEK 293T, Namalwa e Neuro 2A foram submetidos a análise por western blotting utilizando o anti-SAMHD1 monoclonal Origene Technologies. Observa-se a marcação de 3 bandas: uma com massa molecular maior que $66 \mathrm{kDa}$ (1), outra com massa molecular próximo a $66 \mathrm{kDa}$ (2) e uma com massa molecular menor que $66 \mathrm{kDa}$ (3) nos tipos celulares utilizados. A membrana também foi incubada com anticorpo anti-GAPDH como controle de "carregamento". 


\subsection{A hiperexpressão de SAMHD1-HA gera uma proteína SAMHD1 truncada por} tradução alternativa do sítio de iniciação

Subclonamos SAMHD1 humana ( $h S A M H D 1)$ em fusão com HA tag na região Cterminal para hiperexpressar em células HEK 293T (Figura 4). O lisado celular total foi submetido a western blotting e incubado com o anticorpo monoclonal anti-HA (Figura 5). Foram observadas duas bandas proteícas migrando com massas moleculares próximas de 66- e 55-kDa (Figura 5, faixa 1). Uma vez que hSAMHD1 é composta de 626 resíduos de aminoácidos, com peso molecular teórico de $72.2 \mathrm{kDa}$, a pequena banda observada poderia ser uma versão truncada desta proteína.

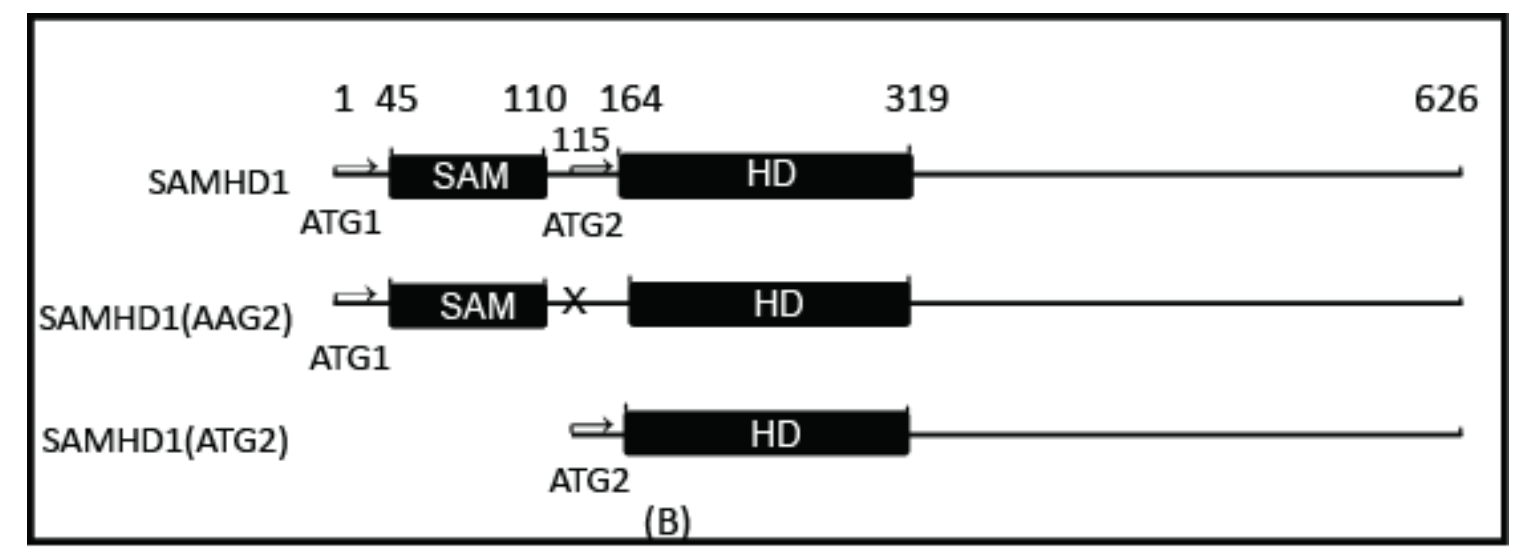

Figura 4: Versões truncadas de SAMHD1. Representação esquemática indicando a posição dos AUGs em transcritos humanos. Os retângulos em preto indicam os domínios de hSAMHD1 descritos. O x indica o local onde foi feita a mutação para deleção do ATG2, e geração dos transcritos SAMHD1(AAG2). 
Para investigar a possibilidade de um sítio alternativo de tradução localizado a 345 nucleotídeos upstream do ATG1, mutamos o ATG2 (nucleotídeos 345 a 347) para AAG, que codifica para SAMHD1(AAG2)-HA (Figura 4). Construímos também a versão truncada da proteína hSAMHD1-HA sem os primeiros 114 aminoácidos, que codifica para SAMHD1(ATG2)-HA (Figura 4) . Os lisados totais de células HEK 293T transfectadas com cada construção foram analisados por western blotting com anticorpo anti-HA. Surpreendentemente, a SAMHD1(AAG2)-HA falhou em gerar uma proteína de 55 kDa ao passo que a proteína SAMHD1(ATG2)-HA migrou como uma única banda de mesmo peso molecular que a pequena SAMHD1-HA (Figura 5).

No geral, a hiperexpressão de hSAMHD1-HA full-length e seus mutantes revelaram a presença de uma versão truncada de $h S A M H D 1$ gerada por um sítio de início de tradução alternativo localizado no nucleotídeo 345 a 347. Esses resultados nos permitem inferir que a banda de $50 \mathrm{kDa}$, reconhecida pelo anticorpo monoclonal da Origene, poderia ser a versão truncada SAMHD1(ATG2). 


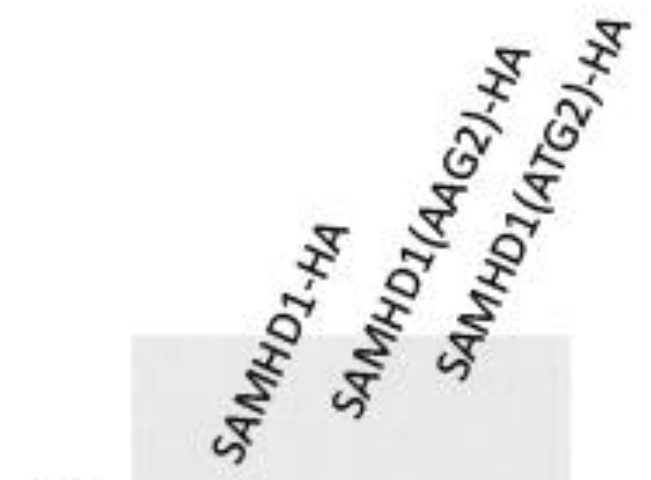

$116-$

66-

$45-$

35-

\section{Anti-HA}

Figura 5: Expressão das versões truncadas de SAMHD1. Lisados de HEK 293T transientemente transfectadas com as construções de SAMHD1 e analisados por western blotting com o anticorpo anti-HA. 
Para confirmar a existência de um sítio alternativo de tradução, células HEK 293T foram transfectadas com siRNA específico para SAMHD1, e processadas para western blotting. Nossos resultados com o anticorpo monoclonal demonstraram que, usando siRNA, nós podemos fazer o knockdown da banda de 66 kDa (banda 2), porém o mesmo não ocorre com a banda 3, de 50 kDa. Esses dados são inconsistentes com a idéia de início de tradução alternativa de SAMHD1 endógena, e que a banda 3 pode ser decorrente de reação cruzada do anticorpo monoclonal (Figura 6). 


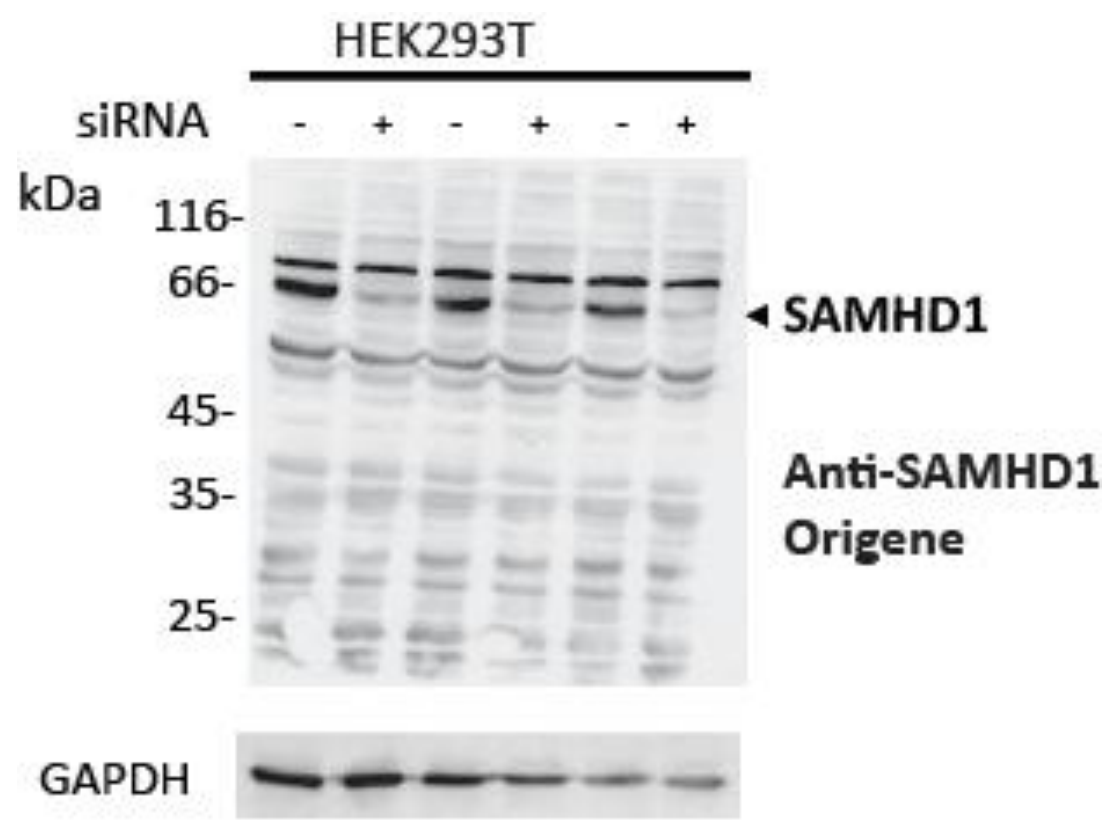

Figura 6: Avaliação do Knockdown de SAMHD1 utilizando siRNA. Células HEK 293T foram transfectadas com siRNA específicos ou não para SAMHD1 e os resultados avaliados por western blotting com o anti-SAMHD1 Origene. A membrana também foi incubada com anticorpo anti-GAPDH como controle de "carregamento". 
Utilizamos, portanto, uma segunda abordagem, células humanas HAP1 nocaute para hSAMHD1 gerada pelo sistema CRISPR/Cas9. A análise de PCR e sequenciamento de Sanger da região genômica alvo confirmaram a presença de uma adição no gene SAMHD1, levando a uma mutação de deslocamento de 2 pares de bases no quadro de leitura e um códon de parada prematuro downstream no éxon 1 de células HAP1 (Anexo 1). Igualmente, o nocaute de SAMHD1 mediada por CRISPR levou à depleção apenas da banda de 66 kDa sem nenhum efeito na banda 2 da proteína de 55 kDa (Figura 7). 


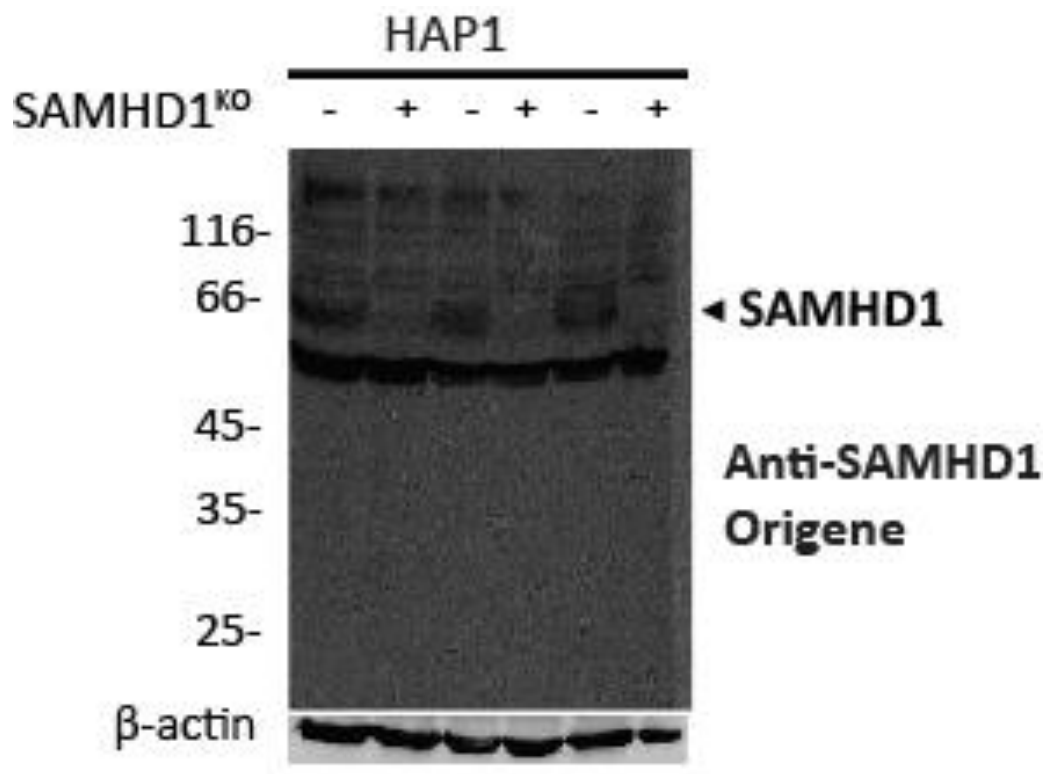

Figura 7: Especificidade do anticorpo anti-SAMHD1 monoclonal Origene. Lisados de células HAP1 parentais e nocautes para SAMHD1 foram analisados por western blotting, utilizando o anti-SAMHD1 monoclonal Origene Technologies. Como controle de "carregamento" foi utilizado o anticorpo anti- $\beta$ actina. 
Os resultados acima mencionados demonstraram que a banda de proteína de $50 \mathrm{kDa}$ observada usando o anticorpo monoclonal foi resultado de reação cruzada do anticorpo monoclonal. Então sentimos a necessidade de utilizarmos um segundo anticorpo antiSAMHD1 para confirmação dos nossos resultados.

Utilizamos o anticorpo anti-SAMHD1 policlonal produzido contra o fragmento $\mathrm{N}$ terminal de 314 aminoácidos de hSAMHD1 (Proteintech Group). Testamos a especificidade do mesmo em lisados de células HEK 293T, e vimos que ao contrário do que ocorre quando utilizamos o anticorpo monoclonal, o anticorpo policlonal reconhece uma única proteína que migra com uma massa molecular próximo a 66 kDa em células HEK 293T (Figura 8). 


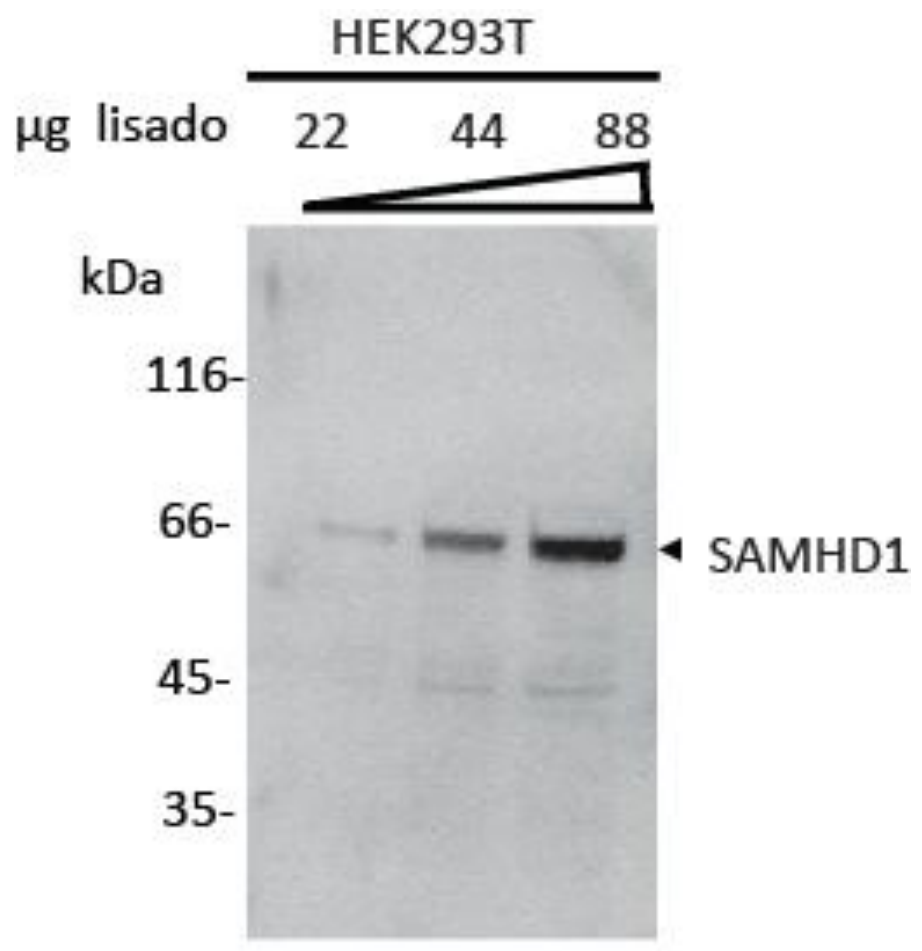

\section{Anti-SAMHD1 Proteintech}

Figura 8: Expressão de SAMHD1 em células HEK 293T, utilizando o anticopo policlonal. Lisados de células HEK 293T foram submetidos a análise por western blotting utilizando o anti-SAMHD1 policlonal Proteintech Group. 
Para reforçar nossos dados, utilizamos da mesma estratégia com siRNA e células HAP1 nocaute para SAMHD1. O anticorpo policlonal marcou somente a banda de $66 \mathrm{kDa}$, como mostra a Figura 9A. Com as células nocaute HAP1, é claro o desaparecimento da banda específica de SAMHD1 de 66 kDa (Figura 9B).

(A)

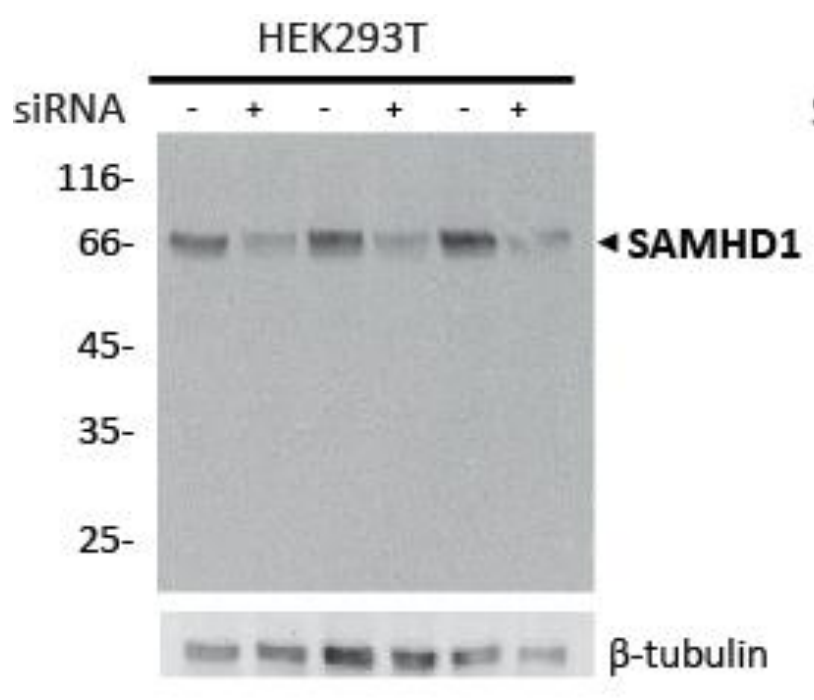

(B)

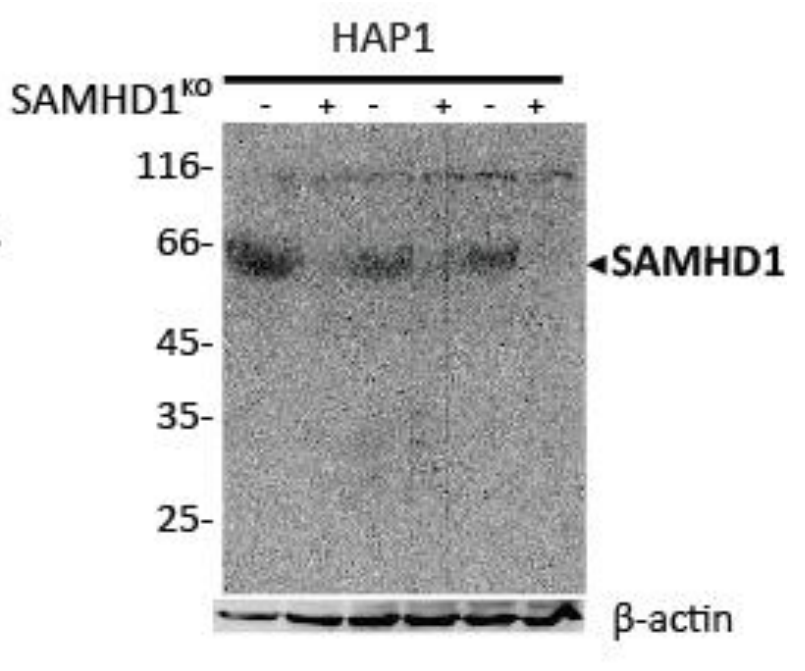

Anti-SAMHD1 Proteintech

Figura 9: Especificidade do anticorpo anti-SAMHD1 policlonal. (A) Lisados de células HEK 293T transfectados com siRNA específicos para SAMHD1, analisados por western blotting com o anticorpo policlonal anti-SAMHD1 Proteintech Group, mostrando o knockdown da banda de 66 kDa. Como controle de "carregamento", foi utilizado o anti- $\beta$-tubulina. (B) Lisados de células HAP1, parental e nocaute para SAMHD1, foram incubados com o anti-SAMHD1 policlonal Proteintech Group, mostrando o knockout específico da banda de $66 \mathrm{kDa}$. Como controle de "carregamento", foi utilizado o anti- $\beta$-actina. 
Para reforçar esse resultado, utilizamos lisados de células Jurkat, que possuem níveis muito baixos de $h S A M H D 1$ (nocaute natural) ${ }^{84}$, em comparação com HEK 293 T para ambos os anticorpos (Figura 10). Os resultados mostram uma banda específica de hSAMHD1 em 66 kDa e provaram a reação cruzada do anticorpo monoclonal anti-SAMHD1 com as bandas 1 e 3 da Figura 4. 


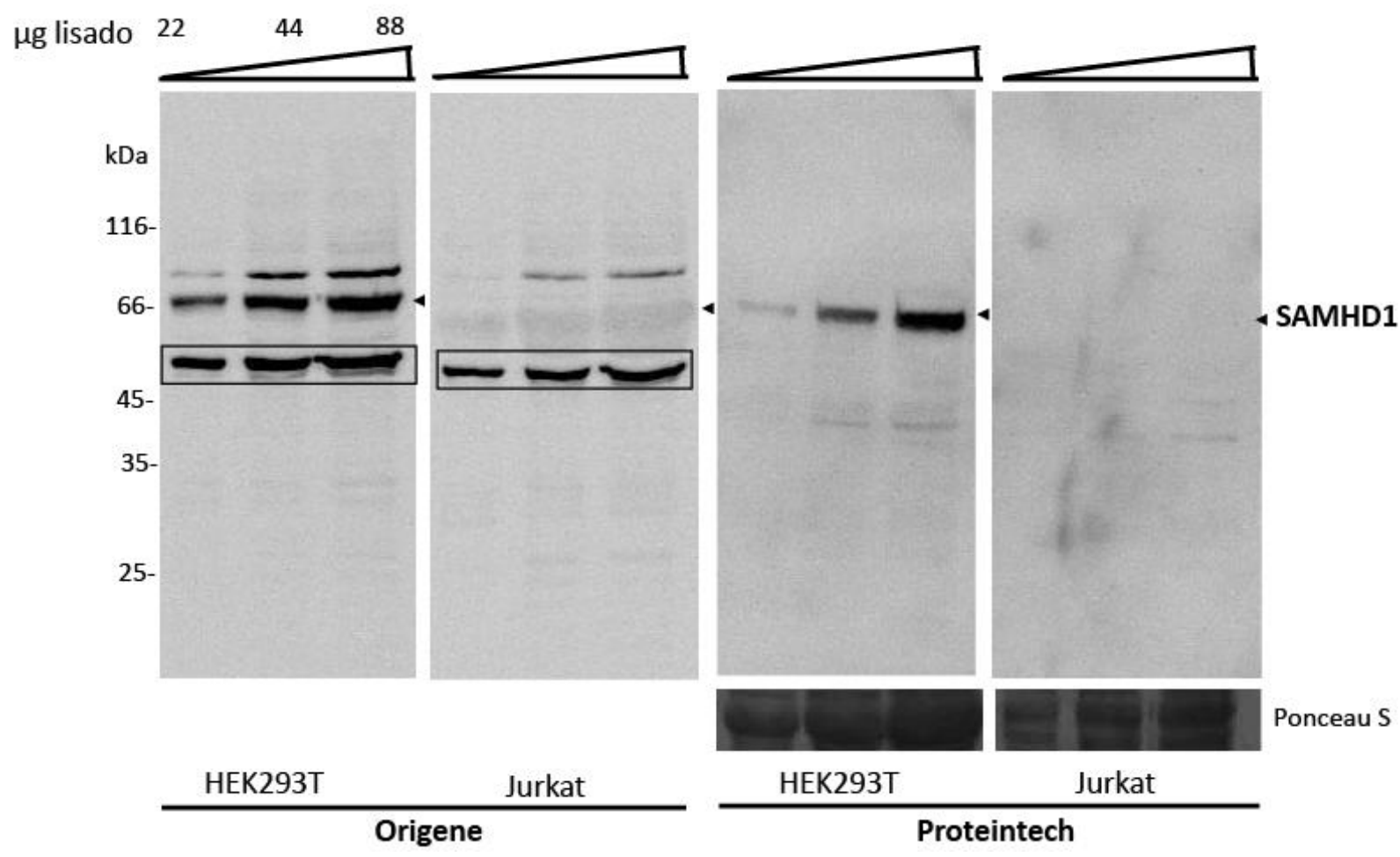

Figura 10: Expressão de hSAMHD1 em células humanas. Extratos celulares foram preparados e analisados por western blotting com anticorpos anti-SAMHD1 monoclonal e policlonal. Como controle de comparação de corrida, utilizamos bandas não específicas do gel coradas com ponceau. 


\subsection{SAMHD1 tem localização nuclear e é recrutada para locais onde há dano no DNA, causada por Camptotecina (CPT).}

Para determinar a localização subcelular de SAMHD1 endógena, nós avaliamos por microscopia confocal a localização desta proteína utilizando anti-SAMHD1 monoclonal (Origene Technologies) e o anti-SAMHD1 policlonal (Proteintech Group), em células HAP1. Ambos apresentaram marcação nuclear, e o anticorpo monoclonal também exibiu estrutura perinuclear dot like que permanece mesmo na linhagem celular HAP-1 nocaute para SAMHD1 (Figura 11, painel superior) indicando que esta marcação é inespecífica do anticorpo. Por outro lado, o anticorpo policlonal não apresentou essas estruturas dot like, e a marcação não foi verificada em células nocautes (Figura 11, painel inferior).

SAMHD1 tem sido descrita como uma proteína essencial no reparo de extremidades do DNA quando há quebra na dupla fita (DSB) por recombinação homóloga (HR) ${ }^{55,56}$. Demonstramos que SAMHD1 é recrutada para os locais de ruptura sob estímulo da droga camptotecina (CPT), que causa danos no DNA, usando o anti-SAMHD1 monoclonal. Embora também observemos um aumento das estruturas dot-like quando utilizamos tratamento com $2 \mu \mathrm{M}$ de CPT por 4h em células HeLa, este efeito não foi observado quando o anticorpo policlonal foi utilizado (Figura 12).

As DSBs provocam uma reação extensa na cromatina vizinha, caracterizada pela fosforilação da histona H2AX na serina 139 de sua cauda C-terminal (para formar " $\gamma H 2 A X$ "). Para avaliar o recrutamento de SAMHD1 para esses locais de dano, analisamos por microscopia confocal a dupla marcação com os anticorpos anti-SAMHD1 e o anti- $\mathrm{pH} 2 \mathrm{AX}$, tratados com CPT. Nós observamos que o anti- $\mathrm{H} 2 \mathrm{AX}$ não colocaliza com o anticorpo 
policlonal de SAMHD1 (Figura 13), e que os dados mostrados por Daddacha et al., 2017, são decorrentes de marcações inespecíficas do anticorpo monoclonal de SAMHD1. 


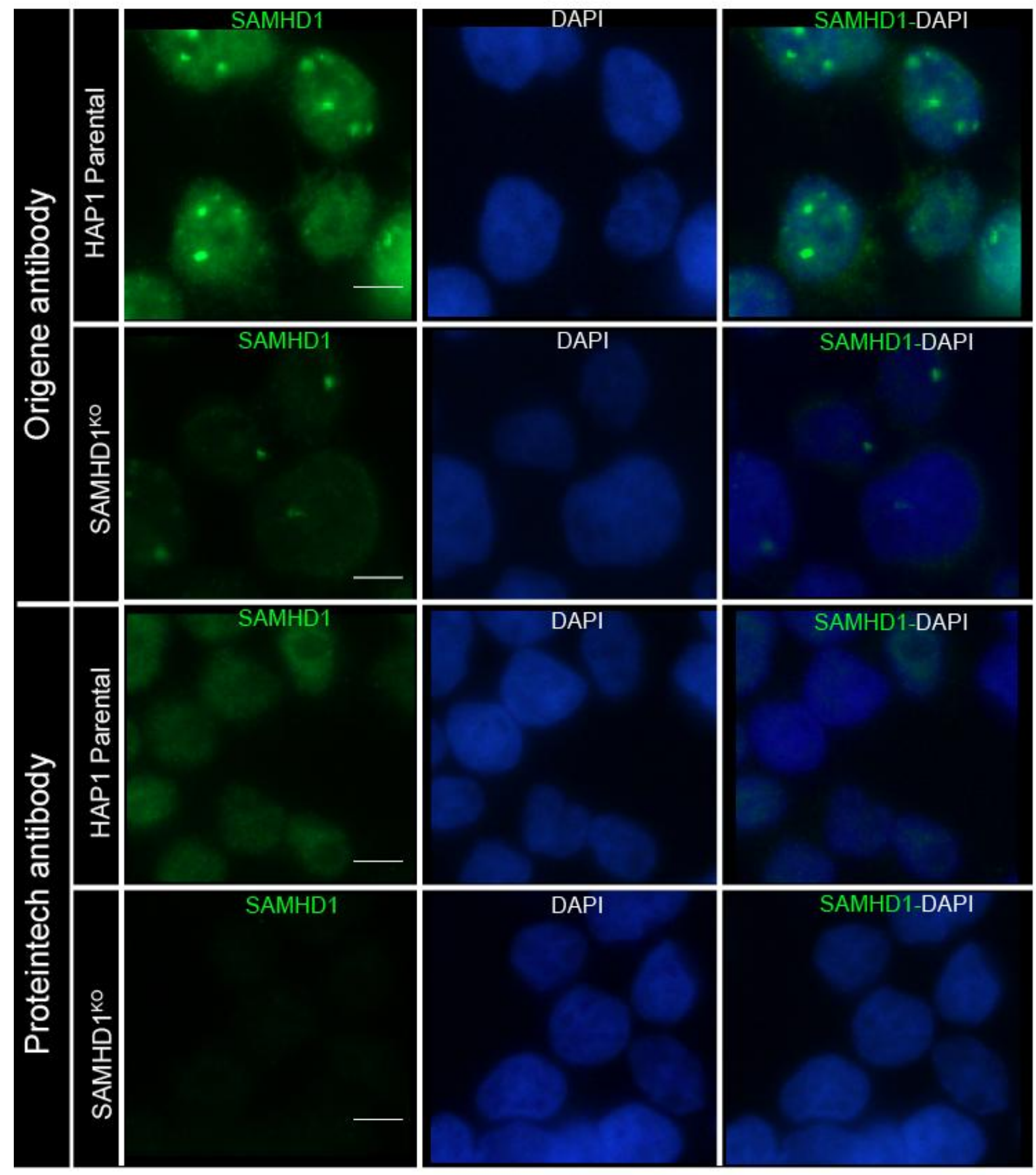

Figura 11: SAMHD1 acumula-se somente no nucleoplasma. Células HAP1 parental e células SAMHD1 ${ }^{\mathrm{KO}}$ foram marcadas com o anti-SAMHD1 (verde) Origene Technologies e com o anti-SAMHD1 Proteintech Group. O núcleo celular foi marcado com DAPI (azul). Note que a estrutura dot-like permanece mesmo na linhagem celular HAP-1 nocaute para SAMHD1 indicando que este sinal é inespecífico para este anticorpo. Barra - $5 \mu \mathrm{m}$. 


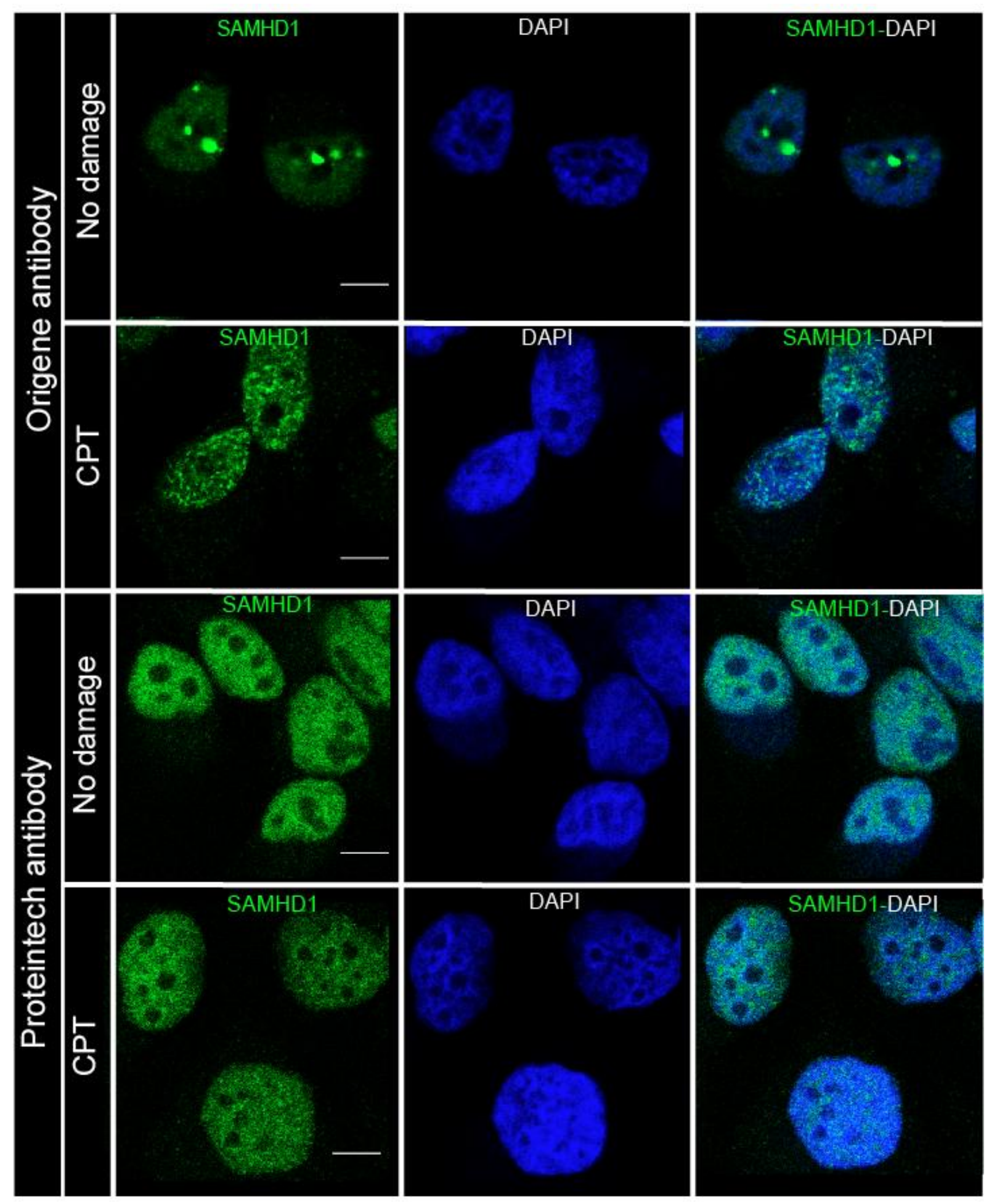

Figura 12: A sinalização de resposta ao dano do DNA não desencadeia a redistribuição de SAMHD1 para foci nucleares. A) As células HeLa foram tratadas com CPT $2 \mu \mathrm{M}$ por 4 horas e processadas para imunofluorescência e análise no confocal com os anticorpos anti-SAMHD1 Origene Technologies e Proteintech Group. Note que o padrão especulado sob estímulos de dano do DNA não foi observado com o anticorpo policlonal específico do Proteintech Group. Barra - $5 \mu \mathrm{m}$. 


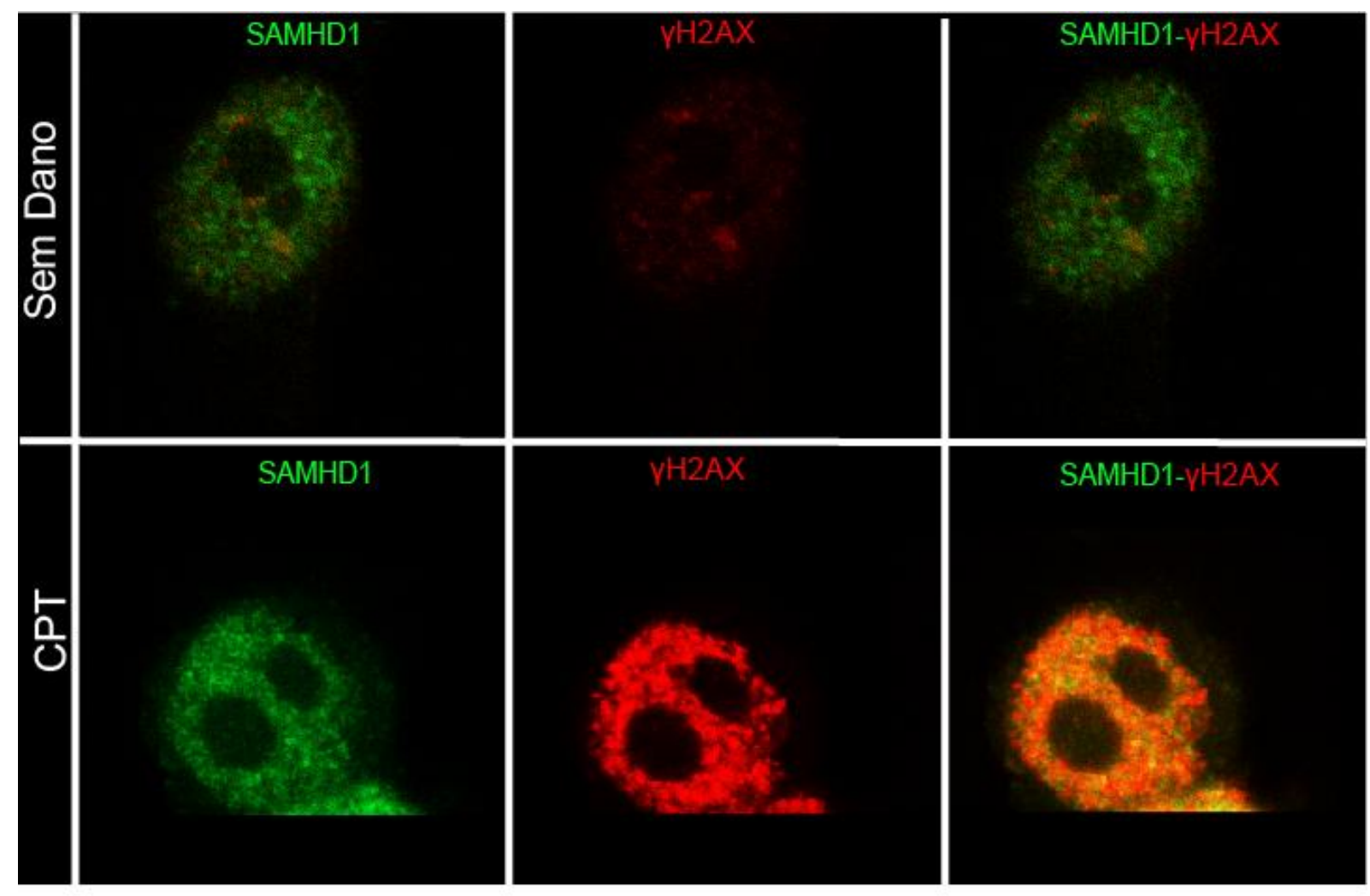

Figura 13: $O$ dano ao DNA induzido por CPT ativa a resposta yH2AX, mas não SAMHD1. Células HeLa foram tratadas com $2 \mu \mathrm{M}$ de CPT durante $4 \mathrm{~h}$ e processadas para análise de microscopia confocal de imunofluorescência, utilizando dupla marcação com o anticorpo policlonal anti-SAMHD1 Proteintech Group (verde) e yH2AX (vermelho). 


\subsection{Avaliação da produção de SAMHD1(ATG2) endógena}

A SAMHD1(ATG2)-HA foi identificada sob condições de hiperexpressão de SAMHD1HA em células HEK 293T, mas não tínhamos avaliado seus níveis de expressão endógenos. Para isso, células HEK 293T foram transfectadas ou não com SAMHD1-HA, SAMHD1(AAG2)HA ou SAMHD1(ATG2)-HA e processadas para western blotting marcando com os anticorpos anti-SAMHD1 monoclonal e policlonal (Figura 14). Nota-se a expressão de SAMHD1(ATG2) somente sob condições de hiperexpressão de SAMHD1-HA ou SAMHD1(ATG2)-HA com ambos os anticorpos (faixas 2, 4, 6 e 8). Como esperado, o mutante SAMHD1(AAG2)-HA não apresentou expressão da SAMHD1(ATG2)-HA (faixas 3 e 7). Esses dados confirmam a falta de um códon de início alternativo endógeno no mRNA de hSAMHD1.

No entanto, uma vez observada à expressão deste códon de início alternativo de SAMHD1 (ATG2) sob a hiperexpressão de SAMHD1-HA do tipo selvagem, a determinação da função desta forma truncada é importante para distingui-la da versão do tipo selvagem em estudos envolvendo a hiperexpressão de SAMHD1. 


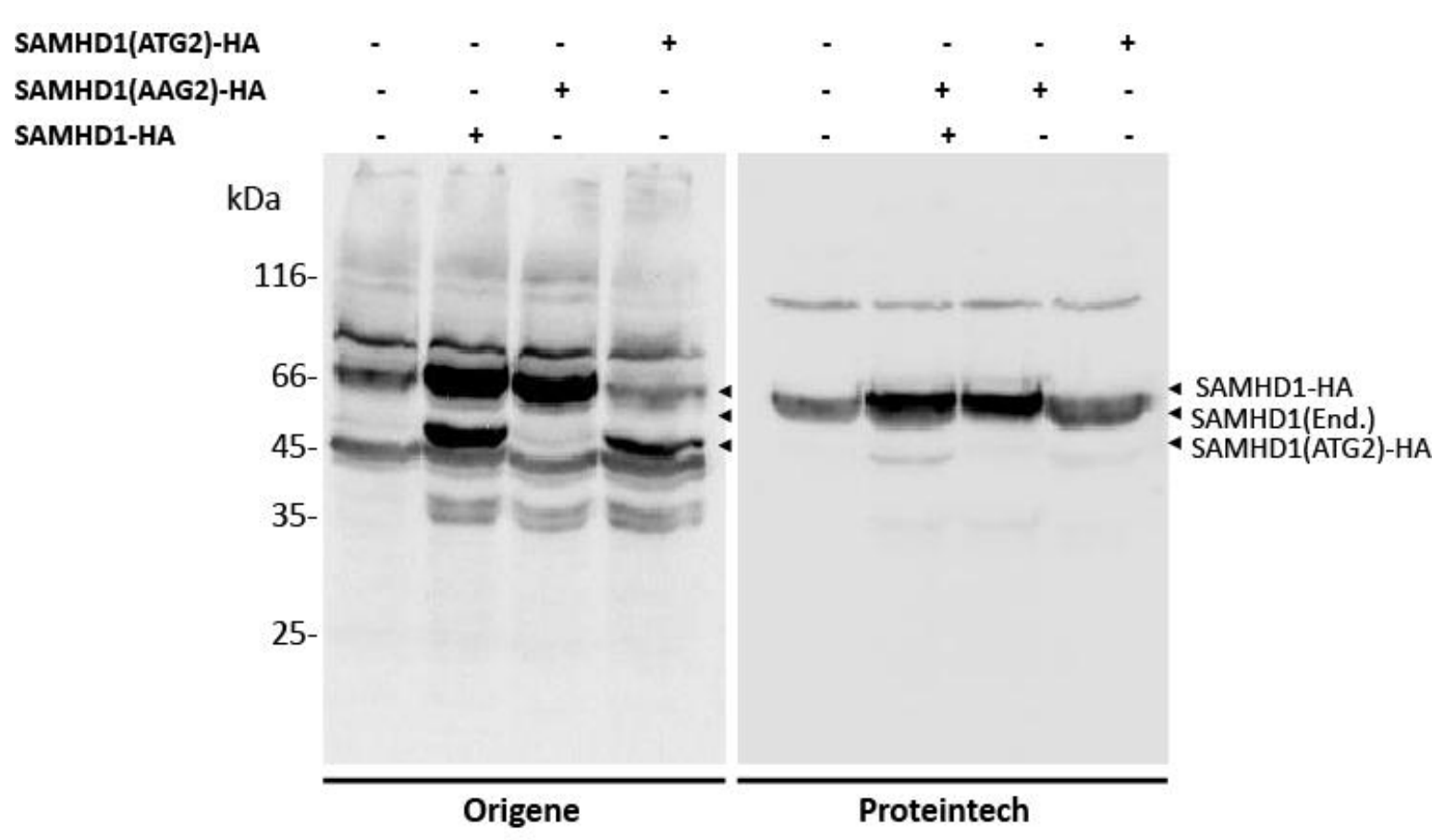

Figura 14: Análise de SAMHD1(ATG2)-HA por western blotting em extratos de células HEK 293T. Células HEK 293T foram transfectadas com vetor vazio, SAMHD1-HA, SAMHD1(AAG2)-HA ou SAMHD1(ATG2)-HA e foram processadas para análises por western blotting, com anticorpos antiSAMHD1 Origene Technologies e Proteintech Group. 


\subsection{Imunopurificação das proteínas reativas ao anticorpo anti-SAMHD1}

\section{monoclonal}

Em nossos estudos, vimos que o anticorpo anti-SAMHD1 Origene Technologies, reage, além de SAMHD1 $(72,2 \mathrm{kDa})$, com uma outra proteína de aproximadamente $50 \mathrm{kDa}$ (p50), por western blotting e que pode ser a proteína formadora do dots observado por microscopia confocal. Para investigar a possibilidade de reação cruzada do anti-SAMHD1, imobilizamos via reagente DMP de crosslinking como um método de imunopurificação. DMP crosslinker pode ser utilizado para imobilizar anticorpos em suportes de agarose conjugadas a proteína A ou proteína $\mathrm{G}$ para imunopurificação do antígeno.

O primeiro passo do processo de imunopurificação da proteína alvo consiste na verificação se o anticorpo anti-SAMHD1 Origene Technologies se ligou corretamente a resina de agarose. Para isso, separamos alíquotas antes da adição do crosslinking (1), após a adição do DMP crosslinking (2) e após a lavagem com o tampão ácido (3) (Figura 15), as quais foram analisadas por western blotting. Assim, conseguimos identificar a ligação bem-sucedida do anti-SAMHD1 a resina de agarose, pois o resultado indicou uma depleção de $\lg$ entre as amostras 1 e 2 (pré e pós-ligação), uma vez que a amostra 1 indica a quantidade de IgG livre, e a amostra 2 a quantidade de IgG que não se ligou à resina (Figura 15). Além disso, a diminuição de IgG na amostra 3 indica a eficiência de ligação à resina, considerando que um crosslinking bem sucedido é indicado pela falta de eluição de IgG após a fervura da resina ${ }^{78}$. 


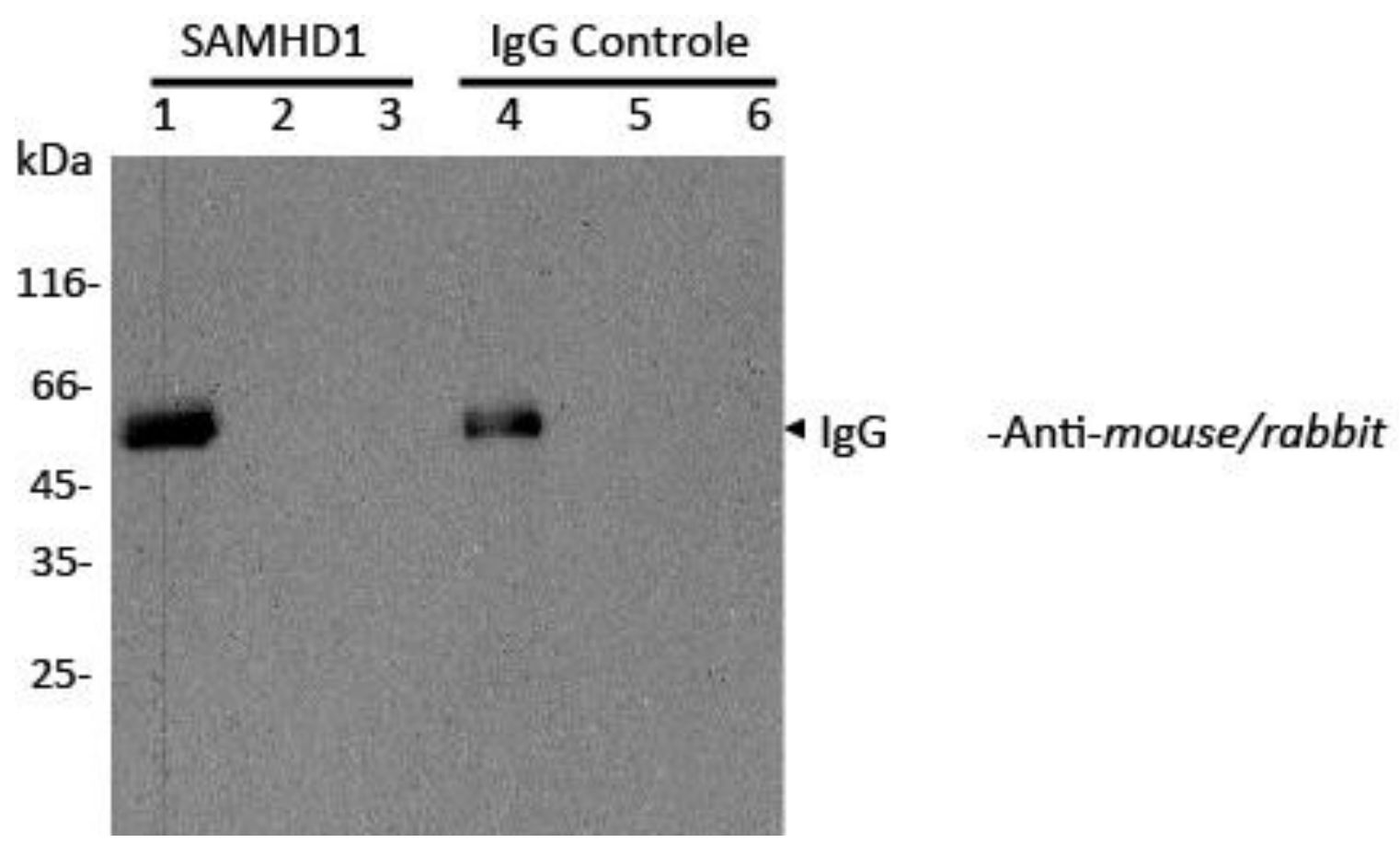

Figura 15: Eficiência de imobilização do anti-SAMHD1 à resina de agarose conjugado à proteína A/G. (1) e (4) representam IgGs livres antes da adição do DMP crosslinking; (2) e (5) representam os IgGs livres após a adição do reagente de crosslinking; (3) e (6) representam os IgGs livres após a lavagem com o tampão ácido. $\mathrm{O}$ anticorpo anti-SAMHD1 foi ligado à resina de agarose conjugado à proteína $A / G$ usando DMP crosslinking. Para revelação da membrana, foi utilizado anticorpo secundário conjugado a peroxidase, anti-mouse e anti-rabbit. 
Em seguida, procedemos com a imunopurificação da proteína alvo a partir de lisados celulares. Para isso, partimos de um total de 8 placas de $10 \mathrm{~cm}$ de HEK 293T, sendo 4 placas para imunopurificação utilizando a resina de agarose conjugada a proteína $A / G$ que foi imobilizada ao IgG controle, e 4 placas utilizando a resina de agarose conjugada a proteína A/G que foi imobilizada ao anti-SAMHD1 Origene Technologies. Após a análise dos resultados da imunopurificação, vimos que a proteína alvo (p50) não foi enriquecida com o processo (Figura 16), dessa forma não foi possível purificar a banda para análise por espectrometria de massas, não sendo possível a identificação dessa proteína por essa metodologia. 


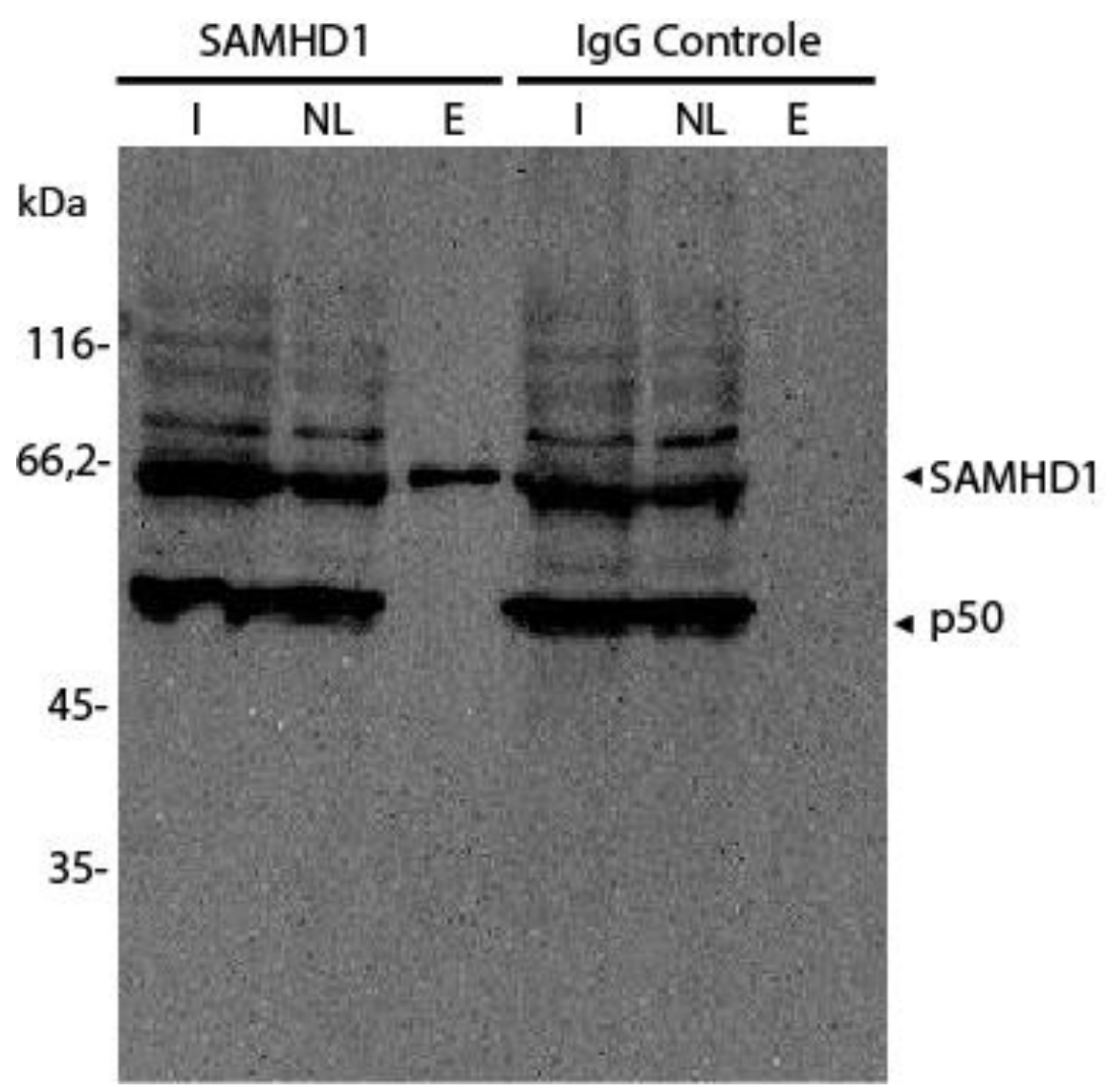

Figura 16: Imunopurificação usando o anticorpo anti-SAMHD1 Origene. Anti-SAMHD1 monoclonal foi covalentemente ligada à resina de agarose conjugada a proteína $A / G$, utilizando DMP crosslinking. (I) Input; (NL) o lisado que não foi ligado á resina; (E) Eluído Glicina 100 mM pH 2-3. 
4.6. Determinação da especificidade do anticorpo anti-SAMHD1 monoclonal utilizando microarranjos de Proteína (Protoarrays ${ }^{\circledR}$ )

Para identificar proteínas que tem reatividade cruzada com esse anticorpo, utilizamos Protoarrays humanos e $0,5 \mu \mathrm{g} / \mathrm{mL}$ do anticorpo anti-SAMHD1 Origene Technologies e como controle, utilizamos uma lâmina apenas incubada com o anticorpo secundário. Utilizando os critérios estatísticos descritos na "Metodologia", identificamos 174 proteínas que reagiram com o anti-SAMHD1 Origene Technologies, subtraindo-se as proteínas marcadas no controle negativo (Anexo 2). Essas proteínas identificadas foram agrupadas, utilizando o PANTHER, de acordo com as suas funções biológicas, sendo grande parte delas $(37,1 \%)$ proteínas que possuem atividade catalítica como SAMHD1, seguidas por proteínas de ligação $(30,5 \%)$, desse total, $38,2 \%$ possuem atividade hidrolase como SAMHD1 (Figura 17). 


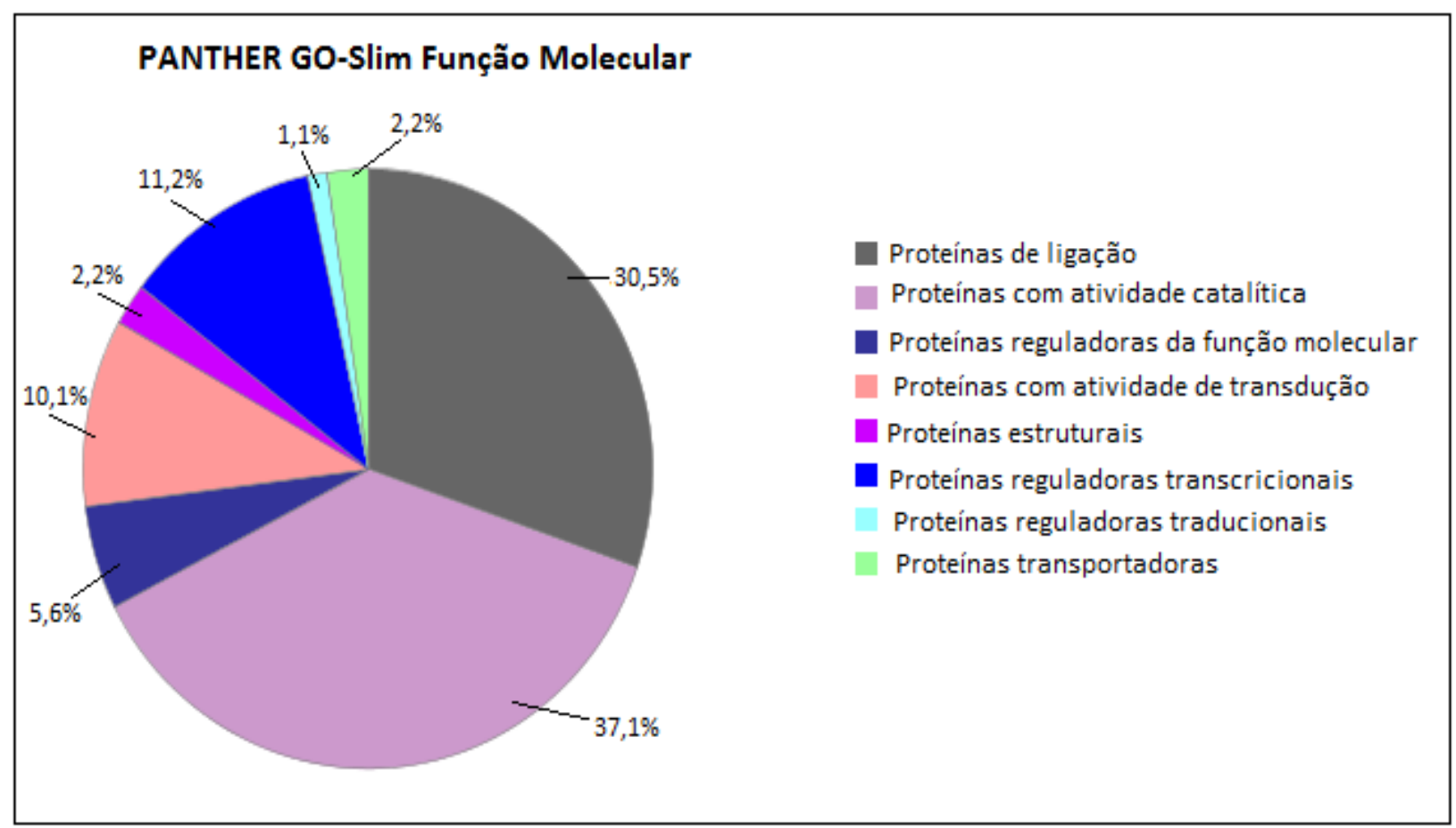

Figura 17: Classificação das proteínas identificadas de acordo com suas funções nas células. As 174 proteínas foram agrupadas 8 diferentes classes de acordo com sua função molecular que vão desde proteínas com atividade catalítica, proteínas de ligação entre outras. 
Como vimos, a proteína reconhecida pelo anti-SAMHD1 Origene Technologies possui, assim como SAMHD1, localização nuclear, então realizamos também a classificação quanto a compartimentalização dessas proteínas na célula usando outra ferramenta, o STRAP1.5. Assim, identificamos um total de 46 proteínas nucleares (22\%) (Figura 18).

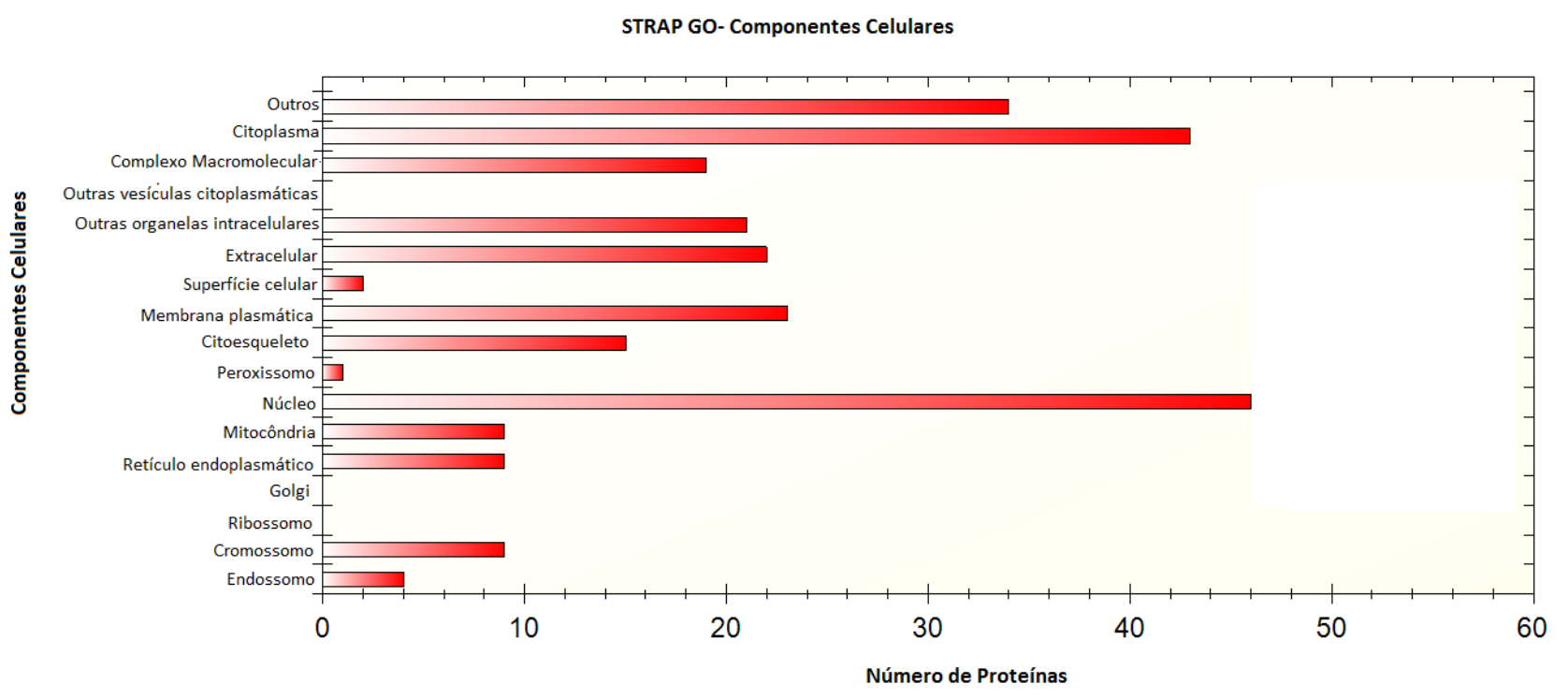

Figura 18: Classificação das proteínas identificadas quanto a sua localização celular. Todas as proteínas identificadas foram agrupadas de acordo com os compartimentos celulares. A grande maioria das proteínas são nucleares ou citoplasmáticas. 
Em seguida, fizemos uma nova seleção de proteínas que se encaixam em todos os parâmetros que havíamos observado: proteína de localização nuclear, com marcação do tipo dots no núcleo e de aproximadamente $50 \mathrm{kDa}$, e conseguimos refinar os dados com a seleção 3 proteínas: RAD51 (DNA repair protein RAD51 homolog 1), GSK3ß (Glycogen synthase kinase-3 beta) e RRAGD (Ras-related GTP-binding protein D) para validação por western blotting utilizando o anti-SAMHD1. Para isso, transfectamos transientemente células HEK 293 T com os respectivos plasmídeos que expressam as proteínas selecionadas e realizamos western blotting marcando-os com o anticorpo anti-SAMHD1 Origene Technologies, e também com o anticorpo anti-HA, uma vez que as construções dos plasmídeos expressam HA tag e anti-actina, como controle de loading.

Infelizmente, o anti-SAMHD1 não reconheceu (por reação cruzada) nenhuma banda correspondente as proteínas superexpressas (Figura 19), utilizando o anticorpo anti-HA, para nenhuma das proteínas testadas, o que demonstra que nenhuma destas proteínas é a p50 observada. 
A)
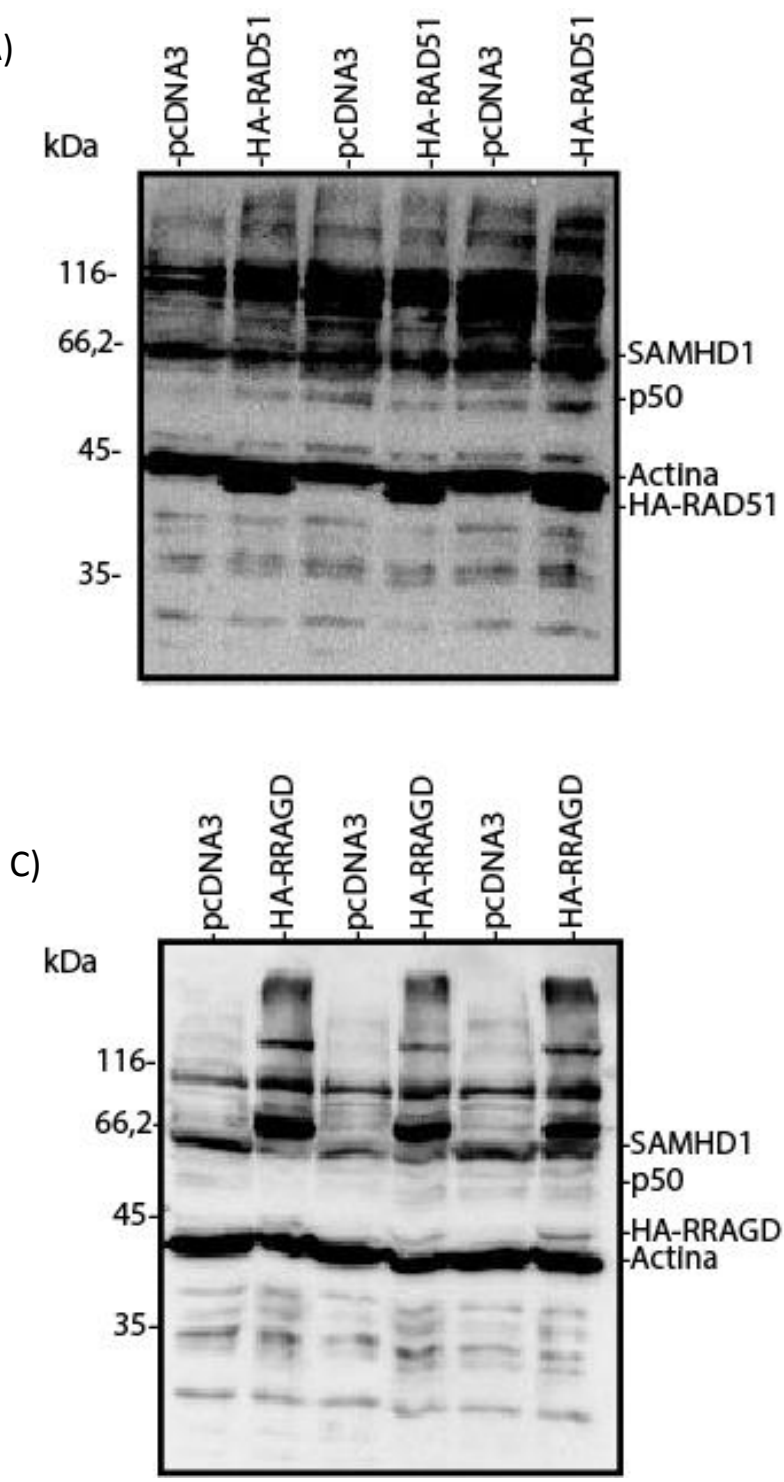

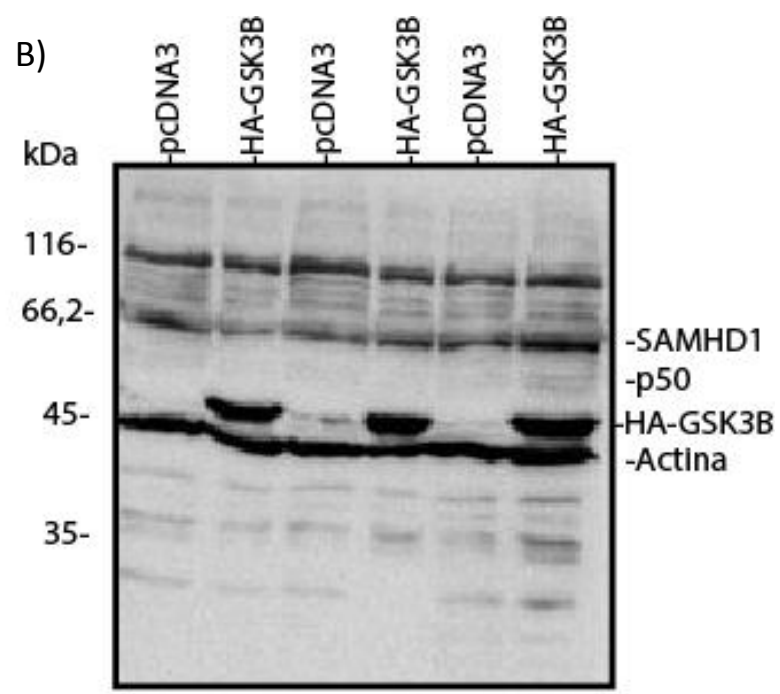

Figura 19: Análise das proteínas identificadas no Protoarray ${ }^{\circledR}$, por western blotting. Células HEK 293T foram transfectadas com plasmídeo vazio e: A) HA-RAD51, B) HA-GSK3 3 ou C) HA-RRAGD. Os lisados celulares foram analisados por western blotting, e incubados com o anticorpo monoclonal anti-SAMHD1, anti-HA e anti-actina, para todas as membranas testadas. 
QDiscussãa 


\section{DISCUSSÃO DE RESULTADOS}

SAMHD1 é conhecida por sua atividade antiviral dependente do GTP que pode reduzir a concentração de dNTPs abaixo de um limiar utilizável para a replicação eficiente do vírus da imunodeficiência humana tipo 1 (HIV-1 ${ }^{13}$. Além disso, uma função independente da sua atividade dNTPásica foi descrita, que é a capacidade de promover a ressecção final do DNA, facilitando o reparo de DSBs por HR ${ }^{56}$. Daddacha et al., 2017, mostraram que SAMHD1 pode ser recrutada para locais onde houve DSBs em resposta a danos no DNA induzidos por CPT em células HeLa e U2OS ${ }^{55,56}$ sendo redistribuída em estruturas dot-like (ou foci) de DSBs.

Durante nossos estudos da função de SAMHD1 no núcleo celular, testamos dois anticorpos: o anti-SAMHD1 monoclonal produzido contra a proteína SAMHD1 inteira, produzida pela Origene Technologies, e o anti-SAMHD1 policlonal criado contra os 314 aminoácidos do fragmento N-terminal de SAMHD1 produzido pelo Grupo Proteintech. Observamos que o anticorpo monoclonal anti-SAMHD1 exibiu os mesmos resultados obtidos por Daddacha et al.,2017 ${ }^{56}$. No entanto, o anticorpo policlonal não confirmou este resultado, mostrando-se sem alterações na distribuição de SAMHD1 após a indução de DSBs. É importante ressaltar que esse mesmo anticorpo monoclonal foi utilizado nos experimentos de colocalização com a proteína FBXO25, no início de nossos estudos, sugerindo maior cautela nas análises de colocalização entre FBXO25 e SAMHD1.

Anticorpos comerciais pouco validados podem gerar resultados inconclusivos. Uma maneira definitiva de demonstrar a especificidade do anticorpo é incorporar o gene nocaute nos procedimentos de validação de anticorpos ${ }^{79}$. Para isso, duas linhas de evidências argumentam contra o recrutamento de SAMHD1 para DSBs em resposta a danos no DNA. (1) 
O anticorpo monoclonal, mas não o anticorpo policlonal, detectou as estruturas dot-like, mesmo nas células $H A P 1^{K O}$, confirmando a não especificidade deste anticorpo. (2) Por análise de western blotting de lisados celulares de HEK 293T transfectados com siRNA para SAMHD1 ou HAP1 ${ }^{\mathrm{KO}}$, demonstramos que uma banda de aproximadamente $50 \mathrm{kDa}(\mathrm{p} 50)$ foi detectada apenas pelo anticorpo monoclonal. Além disso, finalmente, confirmamos a banda inespecífica da proteína p50 pelo anticorpo monoclonal em lisados de células Jurkat, que não expressam SAMHD1.

A aplicação de anticorpos em pesquisas e desenvolvimento de terapias in vitro e in vivo requer que o anticorpo exiba alta especificidade. Apesar de se ligarem com alta afinidade a suas proteínas alvo, os anticorpos podem ter especificidades variáveis ${ }^{80}$. Nesse sentido é importante ressaltar a reatividade cruzada, que é quando um anticorpo reage com sítios antigênicos estruturalmente similares em proteínas diferentes ${ }^{81,82}$. Vimos que o anticorpo monoclonal reconhece três diferentes bandas: uma com massa molecular maior que $66 \mathrm{kDa}$, a segunda com massa molecular próximo a 66 kDa e a terceira, com massa molecular menor que $66 \mathrm{kDa}$ em HEK 293T, enquanto que o anticorpo policlonal, reconhece, com alta especificidade uma única banda de $66 \mathrm{kDa}$. Esses dados, juntos com os resultados de células nocaute e siRNA para SAMHD1, mostraram que o anticorpo monoclonal possui reatividade cruzada com a proteína $\mathrm{p} 50$.

Para identificar novos parceiros de interação o DSP crosslinker tem sido utilizado como uma estratégia de purificação por afinidade aliada a espectrometria de massas ${ }^{83,84}$, sugerindo que o uso de crosslinkers em células pode ser usado caracterizar complexos transitórios por espectrometria de massas. DSP e DMP crosslinker, são utilizados para imobilizar anticorpos a suportes conjugados a proteína A/G para purificação de antígenos ${ }^{85}$. 
Utilizamos DMP crosslinker como estratégia de purificação por afinidade para subsequente análise e identificação por espectrometria de massas. Infelizmente, a p50 não foi enriquecida no nosso eluído, assim, não conseguimos dar prosseguimento com a identificação da p50 utilizando essa estratégia. Assim, podemos inferir que a interação antiSAMHD1 monoclonal com a p50 pode ser fraca e transiente, podendo ter sido rompida durante o procedimento.

Muitos métodos são utilizados para avaliar a especificidade do anticorpo, dentre eles, incluem os arrays de proteínas, western blotting, ELISA e imuno-histoquímica ${ }^{86}$. Em comparação com outros métodos, os arrays de proteínas oferecem várias vantagens, como a triagem rápida de milhares de proteínas em um único dia, e o método de detecção mais sensível do que a deteç̧ão baseada em quimioluminescência usada para western blotting, por exemplo. Uma vez que a identidade de cada proteína impressa no array é conhecida, qualquer reatividade cruzada de anticorpos com proteínas identificadas na matriz pode ser consultada para identificar motivos que podem explicar a reatividade cruzada ${ }^{87}$. Várias publicações demonstraram a utilidade de arrays de proteínas para perfis especificidade de anticorpos ${ }^{88,89,90}$. Assim, utilizamos o Protoarray como ferramenta de identificação de proteínas com reatividade cruzada com o anticorpo anti-SAMHD1 monoclonal, e que se encaixasse nos parâmetros que já havíamos observado: massa molecular ( 50kDa), localização nuclear e estruturas de marcação do tipo dot-like no núcleo. Dessa forma, selecionamos três proteínas: RRAGD, GSK3 $\beta$ e RAD51 que foram analisadas por western blotting, para verificação se o anticorpo monoclonal seria capaz de identificar alguma dessas proteínas superexpressas. 
A proteína RRAGD tem atividade GTPásica está envolvida no controle de mTORC1 e na promoção do crescimento de células cancerígenas ${ }^{91}$. RRAGD não está envolvia no reparo de dano no DNA e não foi reconhecida pelo anticorpo monoclonal por western blotting. Porém, utilizando o programa EMBOSS Water ${ }^{92}$, que realiza a busca por similaridades entre sequências de proteínas, vimos RRAGD possui $33,3 \%$ de similaridade de sequência com SAMHD1, o que poderia explicar a reatividade cruzada com o anticorpo monoclonal de SAMHD1.

GSK3 $\beta$ é uma serina/treonia quinase multifuncional, regulador chave de várias vias de sinalização, como controle do ciclo celular, proliferação, diferenciação e apoptose ${ }^{93,94}$. Em um estudo recente, GSK3 $\beta$ foi translocada do citoplasma para o núcleo, onde induziu o reparo de DNA por DSBs em células de glioblastoma via fosfo-53BP1 ${ }^{95}$, uma importante proteína de checagem de dano no DNA ${ }^{96}$. Além disso, também utilizamos o programa EMBOSS Water ${ }^{92}$, e vimos que GSK3 $\beta$ possui $38,6 \%$ de similaridade de sequência com SAMHD1. Esses dados condiziam com nossos achados até o momento, porém o anticorpo anti-SAMHD1 monoclonal falhou na identificação de HA-GSK3 $\beta$ superexpressa em células HEK 293T.

RAD51 é uma proteína multifuncional que participa de vias centrais de replicação do DNA, reparo por recombinação homóloga, e esta envolvida com o desenvolvimento de câncer ${ }^{97,98}$. Foi proposto um modelo de interação entre RAD51 e a sinalização imunológica em resposta ao dano no DNA e estresse de replicação. RAD51 é recrutado para os locais de DSBs e forquilhas de replicação perturbada, resultando no bloqueio do excesso de atividade de exonuclease de MRE11 no genoma recém-replicado e reparo de DSB. Assim, o RAD51 desempenha um papel direto na replicação do DNA e no reparo de DSBs, e está 
indiretamente envolvida na sinalização imunológica ${ }^{99}$. Assim, RAD51 poderia ser a p50 parceira de interação de SAMHD1, porém o anticorpo monoclonal não reconheceu por western blotting a proteína superexpressa, mesmo com 32,1 \% de similaridade de sequência com SAMHD1.

Além da reatividade cruzada com o anticorpo monoclonal de SAMHD1, que permite que o anticorpo reconheça a p50, devemos considerar também o início alternativo de tradução (TIS), responsável por gerar proteínas truncadas no N-terminal com diferentes funções ${ }^{100}$. Esse processo é responsável pela complexidade e variabilidade do proteoma. 0 início da tradução da maioria dos mRNAs eucarióticos ocorre por varredura linear, embora alguns outros mecanismos também sejam possíveis ${ }^{101-103}$. De acordo com o modelo de varredura, subunidades ribossômicas 40 S são recrutadas para a estrutura terminal cap-5', e a varredura do mRNA ocorre na direção $5^{\prime} \rightarrow 3^{\prime}$. O reconhecimento do tripleto AUG como TIS depende do seu contexto nucleotídico: se o contexto é ótimo, a maioria das subunidades ribossômicas 40 S reconhecerá o AUG e iniciará a tradução. No entanto, se o contexto estiver abaixo do ideal, algumas subunidades reconhecem-no como um TIS, mas outras podem ignorá-lo e continuar a varredura na direção $3^{\prime}$ e iniciar a tradução no primeiro AUG que encontrar (mecanismo de varredura com vazamento). Sendo assim, a varredura do mRNA depende do contexto AUG. ${ }^{104}$. O mRNA transcrito do gene MDM2 humano produz uma proteína p90 (comprimento total) e uma proteína p75 que é uma mistura truncada de isoformas da proteína produzidas pelo início da síntese proteica em códons AUG internos na posição 62 ou 102, respectivamente ${ }^{105}$. Essas proteínas são funcionalmente diferentes, e outros exemplos foram encontrados para os mRNAs de p53 ${ }^{106}$, Sgk1 de camundongo (quinase 1 induzida por soro e glicocorticóide) ${ }^{107}$ e um regulador de sinalização de proteína G (RGS2) e glicocorticóide humano receptor (hGRalpha) ${ }^{108,109}$. Aqui, descobrimos que o 
RNAm de SAMHD1 produziu duas isoformas de SAMHD1 sob hiperexpressão, uma SAMHD1 de tipo selvagem e uma SAMHD1(ATG2) truncado no $\mathrm{N}$-terminal sem os 114 primeiros aminoácidos, incluindo o domínio SAM. Essas isoformas podem ter atividades não identificadas. Esses resultados sugerem a indução do mecanismo de vazamento durante a varredura do TIS de um gene hiperexpresso, recomendando uma cautela durante a hiperexpressão de um gene devido a eventos fora do alvo.

Em resumo, nesse trabalho vimos que a proteína SAMHD1 produziu duas isoformas sob condições de hiperexpressão, uma SAMHD1 do tipo selvagem e uma SAMHD1(ATG2) truncada no N-terminal sem os 114 primeiros aminoácidos, em decorrência de um start códon alternativo sugerindo cautela em experimentos de hiperexpressão. Além disso, vimos que SAMHD1 é recrutada para os locais onde houve DSBs, mas que ao contrário do que foi apresentado em um trabalho anterior ${ }^{56}$, a sinalização em resposta ao dano no DNA não levou a redistribuição de SAMHD1 para o foci nuclear. Por fim, observamos que o anticorpo monoclonal anti-SAMHD1 Origene Technologies possui reatividade com uma proteína de aproximadamente $50 \mathrm{kDa}(\mathrm{p} 50)$, que não conseguimos identificar pelas metodologias utilizadas, portanto continua sem sua função estabelecida. Assim, novas metodologias precisam ser utilizadas na tentativa de identificar a p50 e sua função relacionada às proteínas SAMHD1 e FBXO25, e a sua resposta a danos no DNA. 
Condusães 


\section{Conclusões}

- A proteína SAMHD1 produziu duas isoformas sob condições de hiperexpressão, uma SAMHD1 do tipo selvagem e uma SAMHD1(ATG2) truncada no $\mathrm{N}$-terminal sem os 114 primeiros aminoácidos, incluindo o domínio SAM;

- $\quad$ SAMHD1 é recrutada para os locais onde houve DSBs, ativando a sinalização em resposta ao dano no DNA, porém, sem causar a redistribuição de SAMHD1 para o foci nuclear;

- O anticorpo monoclonal anti-SAMHD1 Origene Technologies possui reatividade com uma proteína de aproximadamente $50 \mathrm{kDa}(\mathrm{p} 50)$, que continua sem identificação, podendo ser a proteína que é recrutada para o foci nuclear em situações de DSBs e colocaliza com FBXO25. 
Oeferéncias OBbliagráficas 


\section{Referências Bibliográficas}

1- L. JIA; Y. SAN. SCF E3 Ubiquitin ligases as anticancer targets. Curr Cancer Drug Targets. 2011; v.11, n.3; p. 347-356.

2- MARAGNO, A.L., BAQUI, M. M. \& GOMES, M. D. FBXO25, na F-box homologue of atrogin-1, is not induced in atrophying muscle. Biochim Biophys Acta. 2006; v.1760, p. 966-972.

3- HAGENS, O., MININA, E., SCHWEIGER, S., ROPERS, H. H. \& KALSCHEUER, V. Characterization of FBX25, enconding a novel brain-expressed F-box protein. Biochim Biophys Acta. 2006; v.1760, p. 110-118.

4- CENCIARELLI, C., et al. Identification of a family of a human F-box proteins. Curr Biol. 1999; V.9, p. 1177-1179.

5- WINSTON , J. T., KOEPP, D. M., ZHU, C., ELLEDGE, S. J. \& HARPER, J. W. A family of mammalian F-box proteins. Curr Biol. 1999 v.9, p. 1180-1182.

6- MANFIOLLI, A.O., et al. FBXO25-associated nuclear domains: a novel subnuclear structure. Mol Biol Cell. 2008; v.19, p. 1848-1861.

7- ZHU, H., et al. Global analysis of protein activities using proteome chips. Science. 2001; v. 293, p. 2101-2105.

8- PERSAUD, A., et al. Comparison of substrate specificity of the ubiquitin ligases Nedd4 and Nedd4-2 using proteome arrays. Mol Syst Biol. 2009; v. 5, p. 333.

9- MERBL, Y. \& KIRSCHNER, M.W. Large-scale detection of ubiquitination substrates using cell extracts and protein microarrays. Proc Natl Acad Sci USA. 2009; v. 106, p. 2543-2548.

10-ANDREWS, P.S., et al. Identification of substrates of SMURF1 ubiquitin ligase activity utilizing protein microarrays. Assay Drug Dev Technol. 2010; v. 8, p. 471-487.

11-TEIXEIRA, FELIPE R.; MANFIOLLI, ADRIANA O.; SOARES, CLAÚDIA S.; BAQUI, MUNIRA M. A.; KOIDE, TIE; GOMES, MARCELO D. The F-box Protein FBXO25 Promotes the Proteasome dependent Degradation of ELK-1 Protein. Journal of Bilogical Chemistry. 2013; V. 288, p.28152-28162.

12-LAGUETTE N, SOBHIAN B, CASARTELLI N, et al. SAMHD1 is the dendritic- and myeloid-cell-specific HIV-1 restriction factor counteracted by Vpx. Nature. 2011;474:654-657.

13- $\mathrm{LI}, \mathrm{MIAOMIAO}$, et al. Roles of SAMHD1 in antiviral defense, autoimmunity and cancer. Rev Med Virol. 2017; 1931.

14-POWELL RD, HOLLAND PJ, HOLLIS T, AND PERRINO FW. Aicardi-Goutieres Syndrome Gene and HIV-1 Restriction Factor SAMHD1 Is a dGTP-regulated Deoxynucleotide Triphosphohydrolase. J. Biol. Chem 2011; e286: 43596-43600.

15- $\mathrm{CHOI} J, \mathrm{RYOO} \mathrm{J}, \mathrm{OH} \mathrm{C}$, HWANG S, AHN K. SAMHD1 specifically restricts retroviruses through its RNase activity. Retrovirology. 2015; e12.

16-HANSEN EC, SEAMON KJ, CRAVENS SL, AND STIVERS JT. GTP activator and dNTP substrates of HIV-1 restriction factor SAMHD1 generate a long-lived activated state. Proc. Natl. Acad. Sci. 2014; e111: E1843-E1851.

17-AMIE SM, BAMBARA RA, AND KIM B. GTP Is the Primary Activator of the Anti-HIV Restriction Factor SAMHD1. J. Biol. Chem. 2013; e288: 25001-25006. 
18-BRANDARIZ-NUÑEZ A, VALLE-CASUSO J, WHITE TE, LAGUETTE $N$, BENKIRANE $M$, BROJATSCH J, AND DIAZ-GRIFFERO F. 2012 Role of SAMHD1 nuclear localization in restriction of HIV-1 and SIVmac. Retrovirology 9: 49.

19-ZIMMERMAN MD, PROUDFOOT M, YAKUNIN A, AND MINOR W. Structural Insight into the Mechanism of Substrate Specificity and Catalytic Activity of an HD-Domain Phosphohydrolase: The 5'-Deoxyribonucleotidase YfbR from Escherichia coli. J. Mol. Biol. 2008; e378: 215-226.

20-ARAVIND L, AND KOONIN EV. 1998 The HD domain defines a new superfamily of metal-dependent phosphohydrolases. Trends Biochem. Sci 23: 469-472.

21-AMIE SM, BAMBARA RA, AND KIM B. GTP Is the Primary Activator of the Anti-HIV Restriction Factor SAMHD1. J. Biol. Chem. 2013; e288: 25001-25006.

22-LAHOUASSA, $\mathrm{H}$. et al. SAMHD1 restricts the replication of human immunodeficiency virus type 1 by depleting the intracellular pool of deoxynucleoside triphosphates. Nat. Immunol. 2012; 13, 223-228.

23-GOLDSTONE DC, et al. HIV-1 restriction factor SAMHD1 is a deoxynucleoside triphosphate triphosphohydrolase. Nature. 2011; 480: 379-382.

24-PAULS, E. et al. Nucleotide embargo by SAMHD1: a strategy to block retroviral infection. Antiviral Res. 2013; 97, 180-182

25-MALUMBRES, M. AND BARBACID, M. Cell cycle, CDKs and cancer: a changing paradigm. Nat. Rev. 2009; Cancer 9, 153-166

26- RENTOFT, $M$ et al. Heterozygous colon cancer-associated mutations of SAMHD1 have functional significance. Proc. Natl. Acad. Sci. USA. 2016; 113, 4723-4728.

27-PAULS, E. et al. p21 regulates the HIV-1 restriction factor SAMHD1. Proc. Natl. Acad. Sci. U.S.A. 2014; 111, E1322-E1324

28-BALLANA, E. and ESTÉ, J. SAMHD1: At the Crossroads of Cell Proliferation, Immune Responses, and Virus Restriction. Trends in Microbiology. 2015; Vol. 23, No. 11.

29- AHN J, HAO C, YAN J, et al. HIV/simian immunodeficiency virus (SIV) accessory virulence factor Vpx loads the host cell restriction factor SAMHD1 onto the E3 ubiquitin ligase complex CRL4DCAF1. J Biol Chem.2012;287:12550-12558.

30-BERGER G, TURPIN J, CORDEIL S, et al. Functional analysis of the relationship between $V p x$ and the restriction factor SAMHD1. J Biol Chem. 2012;287:41210-41217.

31- WEI W, GUO H, HAN X, et al. A novel DCAF1-binding motif required for Vpx-mediated degradation of nuclear SAMHD1 and Vpr-induced G2 arrest. Cell Microbiol. 2012;14:1745-1756

32-RICE, G. I., et al. Mutations involved in Aicardi-Goutières syndrome implicate SAMHD1 as regulator of the innate immune response. Nat. Genet. 2009; 41, 829-832

33-AICARDI, J., AND GOUTIÈRES, F. A progressive familial encephalopathy in infancy with calcifications of the basal ganglia and chronic cerebrospinal fluid lymphocytosis. Ann. Neurol. 1984; 15, 49-54

34-GOUTIÈRES, F. Aicardi-Goutières syndrome Brain Dev. 2005; 27, 201-206

35-GOUTIÈRES, F., AICARDI, J., BARTH, P. G., AND LEBON, P. Aicardi-Goutières syndrome: an update and results of interferon-alpha studies. Ann. Neurol. 1998; 44, 900-907

36- CROW, Y. J. Mutations in the gene encoding the 3'-5' DNA exonuclease TREX1 cause Aicardi-Goutières syndrome at the AGS1 locus. Nat. Genet. 2006; 38,917-920

37- CROW, Y. J., Mutations in genes encoding ribonuclease $\mathrm{H} 2$ subunits cause AicardiGoutières syndrome and mimic congenital viral brain infection. Nat. Genet. 2006; 38, 910-916 
38-CROW, Y. J., and REHWINKEL, J. Aicardi-Goutieres syndrome and related phenotypes: linking nucleic acid metabolism with autoimmunity.Hum. Mol. Genet. 2009; 18, R130-136

39-FYE, J. M., OREBAUGH, C. D., COFFIN, S. R., HOLLIS, T., and PERRINO, F. W. Dominant mutation of the TREX1 exonuclease gene in lupus and Aicardi-Goutieres syndrome. J. Biol. Chem. 2011; 286, 32373-32382

40-HÖSS, M., ROBINS, P., NAVEN, T. J., PAPPIN, D. J., SGOUROS, J., AND LINDAHL, T. A human DNA editing enzyme homologous to the Escherichia coli DnaQ/MutD protein. EMBO J. 1999; 18, 3868-3875

41-LEHTINEN, D. A., HARVEY, S., MULCAHY, M. J., HOLLIS, T., and PERRINO, F. W. J. The TREX1 Double-Stranded DNA Degradation Activity Is Defective in Dominant Mutations Associated With Autoimmune Disease Biol. Chem. 2008; 283, 31649-31656

42-MAZUR, D. J., and PERRINO, F. W. Identification and expression of the TREX1 and TREX2 CDNA sequences encoding mammalian 3'-->5' exonucleases. J. Biol. Chem. 1999; 274, 19655-19660

43-OREBAUGH, C. D., FYE, J. M., HARVEY, S., HOLLIS, T., and PERRINO, F. W. J. The TREX1 exonuclease $\mathrm{R} 114 \mathrm{H}$ mutation in Aicardi-Goutières syndrome and lupus reveals dimeric structure requirements for DNA degradation activity. Biol. Chem. 2011; 286, 4024640254

44-STETSON, D. B., KO, J. S., HEIDMANN, T., and MEDZHITOV, R. Trex1 prevents cellintrinsic initiation of autoimmunity. Cell. 2008; 134, 587-598.

45-YANG, Y. G., LINDAHL, T., and BARNES, D. E. Trex1 exonuclease degrades SSDNA to prevent chronic checkpoint activation and autoimmune disease. Cell. 2007; 131, 873886.

46-YAN, N., and LIEBERMAN, J. Gaining a foothold: how HIV avoids innate immune recognition. Curr. Opin. Immunol. 2011; 23, 21-28

47-YAN, N., Regalado-Magdos, A. D., Stiggelbout, B., Lee-Kirsch, M. A., and Lieberman, J. The cytosolic exonuclease TREX1 inhibits the innate immune response to human immunodeficiency virus type 1. Nat. Immunol.2010; 11, 1005-1013

48-COFFIN, S. R., HOLLIS, T., and PERRINO, F. W Functional consequences of the RNase H2A subunit mutations that cause Aicardi-Goutieres syndrome. J. Biol. Chem. 2011; 286, 16984-16991

49-PERRINO, F. W., HARVEY, S., SHABAN, N. M., and HOLLIS, T. J. RNase H2 mutants that cause Aicardi-Goutieres syndrome are active nucleases. Mol. Med. 2009; 87, 25-30

50-GENOVESIO, A. et al., Automated genome-wide visual profiling of cellular proteins involved in HIV infection. Biomol. Screen. 2011; 16, 945-958

51-LEE-KIRSCH, MA. Nucleic acid metabolism and systemic autoimmunity revisited. Arthritis Rheum 2010; 62:1208-1212.

52-FRANZOLIN, E. et al. The deoxynucleotide triphosphohydrolase SAMHD1 is a major regulator of DNA precursor pools in mammalian cells. Proc. Natl. Acad. Sci. 2014; 110, 14272-14277.

53-KOHNKEN, R., KODIGEPALLI, K.M., and WU, L. Regulation of deoxynucleotide metabolism in cancer: novel mechanisms and therapeutic implications. Mol. Cancer 2016; 14, 176.

54-KRETSCHMER, S. et al. SAMHD1 prevents autoimmunity by maintaining genome stability. Ann. Rheum. 2015; Dis. 74, e17. 
55-CLIFFORD, R., LOUIS, T. et al. SAMHD1 is mutated recurrently in chronic lymphocytic leukemia and is involved in response to DNA damage. Blood. 2014; 123, 1021-1031.

56-DADDACHA, W. et al. SAMHD1 Promotes DNA End Resection to Facilitate DNA Repair by Homologous Recombination. Cell Reports. 2017; 20, 1921-1935.

57-LIMBO, O., CHAHWAN, C., YAMADA, Y., DE BRUIN, R.A., WITTENBERG, C., AND RUSSELL, P. Ctp1 is a cell-cycle-regulated protein that functions with Mre11 complex to control double-strand break repair by homologous recombination. Mol. Cell. 2007; 28, 134-146.

58- MAKHARASHVILI, N., et al. Catalytic and noncatalytic roles of the CtIP endonuclease in double-strand break end resection. Mol. Cell. 2014; 54, 1022-1033.

59-SARTORI, A.A., et al. Human CtIP promotes DNA end resection. Nature. 2007; 450, 509-514.

60-WANG,H.,SHAO,Z., SHI, L.Z.,HWANG,P.Y., TRUONG, L.N.,BERNS,M.W.,CHEN,D.J., and $\mathrm{WU}, \mathrm{X}$. CtIP protein dimerization is critical for its recruitment to chromosomal DNA double-stranded breaks. J. Biol. Chem. 2012; 287, 21471-21480.

61-You, Z., Shi, et al. CtIP links DNA double-strand break sensing to resection. Mol. Cell. 2009; 36, 954-969.

62-ANAND, R., RANJHA, L., CANNAVO, E., AND CEJKA, P. Phosphorylated CtIP functions as a Co-factor of the MRE11-RAD50-NBS1 endonuclease in DNA end resection. Mol. Cell. 2016; 64, 940-950.

63-CANNAVO, E., AND CEJKA, P. Sae2 promotes dsDNA endonuclease activity within Mre11-Rad50-Xrs2 to resect DNA breaks. Nature. 2014; 514, 122-125.

64-GARCIA, V., PHELPS, S.E., GRAY, S., and NEALE, M.J. Bidirectional resection of DNA double-strand breaks by Mre11 and Exo1. Nature. 2011; 479, 241-244.

65- NICOLETTE, M.L., LEE, K., GUO, Z., RANI, M., CHOW, J.M., LEE, S.E., and PAULL, T.T. Mre11-Rad50-Xrs2 and Sae2 promote 50 strand resection of DNA double-strand breaks. Nat. Struct. Mol. Biol.2010; 17, 1478-1485.

66-PAULL, T.T., and GELLERT, M. The 30 to 50 exonuclease activity of Mre 11 facilitates repair of DNA double-strand breaks. Mol. Cell. 1998; 1, 969-979.

67-STRACKER, T.H., and PETRINI, J.H. The MRE11 complex: starting from the ends. Nat. Rev. Mol. Cell Biol. 2011; 12, 90-103.

68-CEJKA, P., PLANK, J.L., BACHRATI, C.Z., HICKSON, I.D., and KOWALCZYKOWSKI, S.C. Rmi1 stimulates decatenation of double Holliday junctions during dissolution by Sgs1Top3. Nat. Struct. Mol. Biol. 2010; 17, 1377-1382.

69-GRAVEL, S., CHAPMAN, J.R., MAGILL, C., and JACKSON, S.P. DNA helicases Sgs1 and BLM promote DNA double-strand break resection. Genes Dev. 2008; 22, 2767-2772.

70-MIMITOU, E.P., and SYMINGTON, L.S. Sae2, Exo1 and Sgs1 collaborate in DNA doublestrand break processing. Nature. 2008; 455, 770-774.

71-NIMONKAR, A.V. et al. S.C. BLM-DNA2-RPAMRN and EXO1-BLM-RPA-MRN constitute two DNA end resection machineries for human DNA break repair. Genes Dev.2011; 25, 350-362.

72- NIU, H., et al. Mechanism of the ATP-dependent DNA end-resection machinery from Saccharomyces cerevisiae. Nature. 2010; 467 108-111.

73-ZHU, C., et al. Structural insight into dGTP-dependent activation of tetrameric SAMHD1 deoxynucleoside triphosphate triphosphohydrolase. Nat. Commun. 2013; 4, 2722. 
74-PRAKASH, R., ZHANG, Y., FENG, W., and JASIN, M. Homologous recombination and human health: the roles of BRCA1, BRCA2, and associated proteins. Cold Spring Harb. Perspect. Biol.2015; 7, a016600.

75-ZHANG, H., et al. ATRIP deacetylation by SIRT2 drives ATR checkpoint activation by promoting binding to RPA-ssDNA. Cell Rep. 2016; 14, 1435-1447.

76-ZHENG, Q. et al., Precise gene deletion and replacement using the CRISPR/Cas9 system in human cells. Biotechniques. 2014 Sep 1;57(3):115-24

77- DE SILVA S, HOY H, HAKE TS, WONG HK, PORCU P, WU L.. Promoter methylation regulates SAMHD1 gene expression in human CD4 T cells. J. Biol. Chem. 2013; 288:9284-9292

78-SMITH, A. L., FRIEDMAN, D.B., YU, H., CARNAHAN, R.H., REYNOLDS, A. B. ReCLIP (Reversible Cross-Link Immuno-Precipitation): An Efficient Method for Interrogation of Labile Protein Complexes. PLoS ONE. 2011; 6(1): e16206.

79-RHODES, K.J. , TRIMMER, J.S. Antibody-based validation of CNS ion channel drug targets J. Gen. Physiol. 2008; 131 pp. 407-413.

80-GATTO, B. Monoclonal antibodies in cancer therapy. Curr Med Chem Anti-Canc Agents 2004; 4, 411-4.

81-https://www.ptglab.com/news/blog/how-do-i-know-if-the-antibody-will-cross-react/ Acessado em: 22/05/2019

82-AALBERSE, R. C., AKKERDAAS, J. H., VAN REE, R.Cross-reactivity of IgE antibodies to allergens. Allergy. 2001; 56: 478-490

83-SALAZAR G, ZLATIC S, CRAIGE B, PEDEN AA, POHL J, et al. Hermansky-Pudlak syndrome protein complexes associate with phosphatidylinositol 4-kinase type II alpha in neuronal and non-neuronal cells. J Biol Chem. 2009; 284: 1790-1802.

84-HUMPHRIES JD, BYRON A, BASS MD, CRAIG SE, PINNEY JW, et al. Proteomic Analysis of Integrin-Associated Complexes Identifies RCC2 as a Dual Regulator of Rac1 and Arf6. Science Signaling. 2009; 2: ra51-ra51.

85-Thermo Scientific Crosslinking Technical Handbook. Disponível em: http://tools.thermofisher.com/content/sfs/brochures/1602163-Crosslinking-

Reagents-Handbook.pdf Acessado em:05/05/2019

86-MICHAUD, G. A. et al. Analyzing antibody specificity with whole proteome microarrays. Nat Biotechnol. 2003; 21, 1509-12.

87-Antibody Profiling on Invitrogen ProtoArray ${ }^{\mathrm{TM}}$ High-Density Protein Microarrays. Disponível em: www.invitrogen.com/protoarray

88-CREANEY, J., DICK, I. A., MUSK, W. OLSEN, N. \& ROBINSON, B. W. S. Immune response profiling of malignant pleural mesothelioma for diagnostic and prognostic biomarkers. Biomarkers, 2016; 21:6, 551-561

89-TUREWICZ, MICHAEL et al. Improving the default data analysis workflow for large autoimmune biomarker discovery studies with ProtoArrays. Proteomics 2013;vol. 13,14, 2083-7.

90-MAY, CAROLINE et al. Highly immunoreactive IgG antibodies directed against a set of twenty human proteins in the sera of patients with amyotrophic lateral sclerosis identified by protein array. PloS one. 2014; vol. 9,2 e89596.

91-DI MALTA C, SICILIANO D, CALCAGNI A, et al. Transcriptional activation of RagD GTPase controls mTORC1 and promotes cancer growth. Science. 2017; 356(6343):1188-1192. doi:10.1126/science.aag2553

92-SMITH, T. F., Waterman MS. J. Mol. Biol. 1981; 147(1);195-7 
93-YANG, Y., LEI, T., DU, S., et al. Nuclear GSK3B induces DNA double-strand break repair by phosphorylating 53BP1 in glioblastoma. Int J Oncol. 2018;52(3):709-720.

94-DOBLE, B. W., WOODGETT, J. R. GSK-3: Tricks of the trade for a multi-tasking kinase. J Cell Sci. 2003;116:1175-1186.

95-HOEFLICH, K.P., LUO, J., RUBIE, E. A., TSAO, M. S., JIN, O., WOODGETT, J. R. Requirement for glycogen synthase kinase-3beta in cell survival and NF-kappaB activation. Nature. 2000;406:86-90.

96- ABRAHAM RT. Checkpoint signalling: Focusing on 53BP1. Nat Cell Biol. 2002;4:E277E279

97-PETERMANN, E., ORTA, M.L., ISSAEVA, N., SCHULTZ N., HELLEDAY, T. Hydroxyureastalled replication forks become progressively inactivated and require two different RAD51-mediated pathways for restart and repair. Mol. Cell. 2010; 37:492-502.

98- HASHIMOTO, Y., RAY CHAUDHURI, A., LOPES, M., COSTANZO, V. Rad51 protects nascent DNA from Mre11-dependent degradation and promotes continuous DNA synthesis. Nat. Struct. Mol. Biol. 2010; 17:1305-1311

99-BHATTACHARYA, S., SRINIVASAN, K., ABDISALAAM, S., et al. RAD51 interconnects between DNA replication, DNA repair and immunity. Nucleic Acids Res. 2017;45(8):4590-4605.

100- BAZYKIN, G.A., KOCHETOV, A.V. Alternative translation start sites are conserved in eukaryotic genomes. Nucleic Acids Res. 2011, 39, pp. 567-577

101- KOZAK, M. Regulation of translation via mRNA structure in prokaryotes and eukaryotes. Gene. 2005; 361:13-37.

102- JACKSON, RJ. Alternative mechanisms of initiating translation of mammalian mRNAs. Biochem Soc Trans. 2005; 33:1231-1241.

103- BAIRD SD, TURCOTTE M, KORNELUK RG, HOLCIK M. Searching for IRES. RNA 2006; 12:1755-1785.

104- KOCHETOV, A.V. Alternative translation start sites and hidden coding potential of eukaryotic mRNAs. Bioessays: News Rev. Mol. Cell Dev. Biol., 2008; 30, pp. 683-691

105- $\quad$ CHENG, T.H., COHEN, S.N. Human MDM2 isoforms translated differentially on constitutive versus p53-regulated transcripts have distinct functions in the p53/MDM2 and TSG101/MDM2 feedback control loops. Mol. Cell Biol. 2007; 27, pp. 111-119

106- COURTOIS, S., et al. DeltaN-p53, a natural isoform of p53 lacking the first transactivation domain, counteracts growth suppression by wild-type p53. Oncogene. 2002; 22, pp. 6722-6728

107- ARTEAGA, M.F.,. AlVAREZ DE LA ROSA, D, ALVAREZ, J.A., CANESSA, C.M. Multiple translational isoforms give functional specificity to serum- and glucocorticoid-induced kinase 1. Mol. Biol. Cell. 2007; 18, pp. 2072-2080

108- GU, S., ANTON, A., SALIM, S., BLUMER, K.J., DESSAUER, C.W. HEXIMER, S.P. Alternative translation initiation of human regulators of G-protein signaling-2 yields a set of functionally distinct proteins. Mol. Pharmacol., 2008; 73, pp. 1-11

109- $\quad$ YUDT, M.R., CIDLOWSKI, J.A. Molecular identification and characterization of a and $b$ forms of the glucocorticoid receptor. Mol. Endocrinol., 2001; 15, pp. 1093-1103 
Aneacas 
Anexo 1

\section{Sequenciamento da célula HAP1 knockout para SAMHD1}

(A)

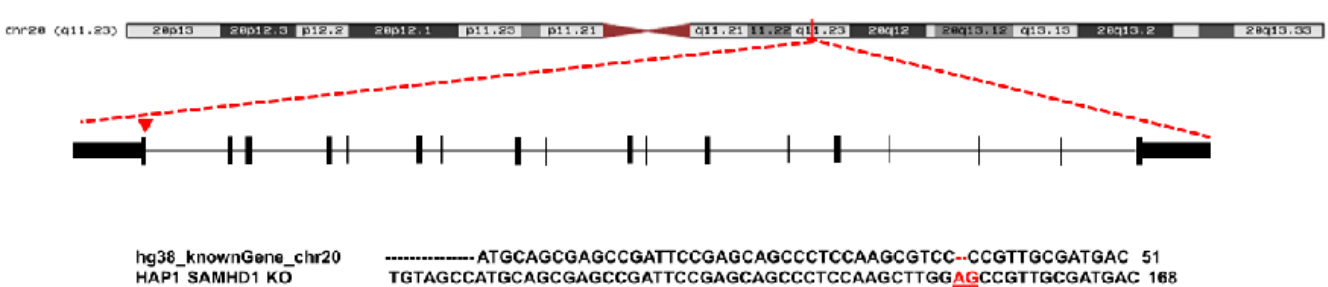

(B)

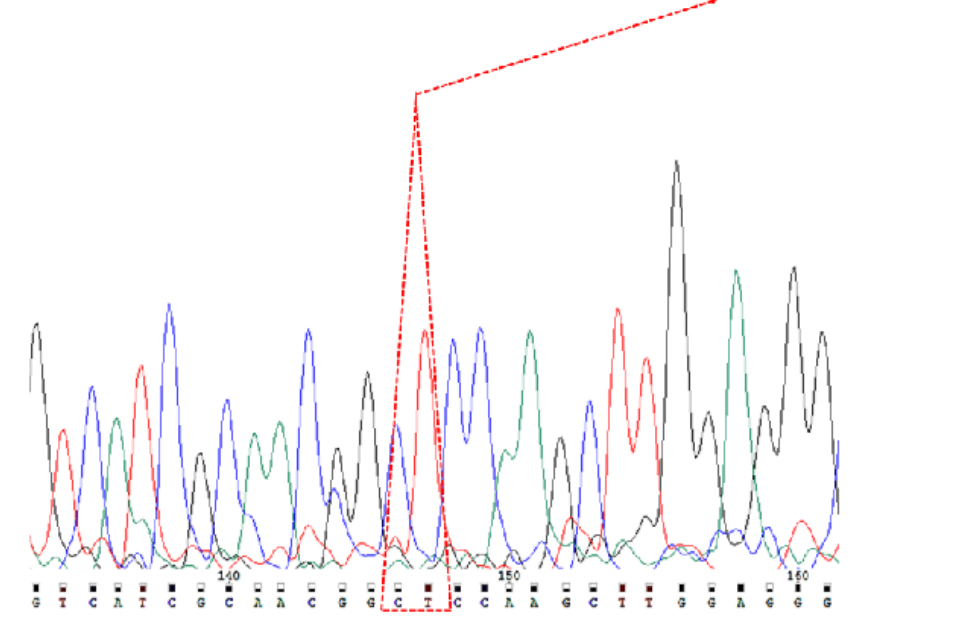

(A) Representação esquemática do locus de SAMHD1 humana, mostrando o sítio alvo usado para geração da linhagem knockout, gerada a partir da edição do genoma mediado por CRISPR/Cas9. (B) Análise do DNA genómico das células HAP1, por PCR. 
ANEXO 2:

Proteínas com reatividade cruzada com o anticorpo monoclonal anti-SAMHD1 Origene Technologies, identificadas com o Protoarray ${ }^{\circledR}$

\begin{tabular}{|c|c|c|c|}
\hline Gene & Localização celular & Tamanho (kDa) & Nome completo do gene \\
\hline ABCF3 & Membrana & 79 & Cassete de ligação a ATP, sub-familia F (GCN20), membro 3 (ABCF3) \\
\hline ABL1 & Mitocondria/Citoplasma/ Nuclear & 122 & $\begin{array}{l}\text { v-abl Abelson murine leukemia viral oncogene homolog } 1 \text { (ABL1), transcript variant } \\
\text { a; }\end{array}$ \\
\hline AK2 & Mitocondria & 26,4 & adenylate kinase 2 (AK2), transcript variant $A K 2 A$ \\
\hline ALG13 & Retículo endoplasmatico & 126 & asparagine-linked glycosylation 13 homolog (S. cerevisiae) (ALG13) \\
\hline ARHGEF5 & Nuclear /Citoplasma & 126 & Rho guanine nucleotide exchange factor (GEF) 5 (ARHGEF5) \\
\hline ARL6 & Membrana & 21 & ADP-ribosylation factor-like 6 (ARL6), transcript variant 1 \\
\hline ARMCX3 & Nuclear /Mitocondria & 42,5 & armadillo repeat containing, $\mathrm{X}$-linked 3 (ARMCX3), transcript variant 1 \\
\hline ATM & Nuclear & 350 & Serine-protein kinase ATM \\
\hline BCL2L13 & Nuclear & 52 & BCL2-like 13 (apoptosis facilitator) (BCL2L13) \\
\hline BIRC5 & Nuclear & 16,3 & baculoviral IAP repeat-containing 5 (survivin) (BIRC5), transcript variant 1 \\
\hline BLOC1S6 & Membrana/Citoplasma & 19,7 & Biogenesis of lysosome-related organelles complex 1 subunit 6 \\
\hline BRSK2 & Retículo/Citoesqueleto & 89 & BR serine/threonine kinase 2 (BRSK2) \\
\hline
\end{tabular}




\begin{tabular}{|c|c|c|c|}
\hline C11orf54 & Nuclear & 35,11 & Ester hydrolase C11orf54 \\
\hline C7orf53 & Membrana & 14,4 & $\begin{array}{l}\text { Coiled-coil domain-containing transmembrane protein C7orf53/ Leucine-rich single- } \\
\text { pass membrane protein } 1\end{array}$ \\
\hline CA2 & Membrana & 29,2 & carbonic anhydrase II (CA2) \\
\hline CAB39L & Citosol & 39 & Calcium-binding protein 39-like \\
\hline CAMK2N1 & Membrana & 8,5 & calcium/calmodulin-dependent protein kinase II inhibitor 1 (CAMK2N1) \\
\hline CANT1 & Golgi/Membrana/Retículo & 44,8 & calcium activated nucleotidase 1 (CANT1) \\
\hline CCDC59 & Nuclear & 28,6 & coiled-coil domain containing 59 (CCDC59) \\
\hline CCL17 & Secretado & 10,5 & $\mathrm{C}-\mathrm{C}$ motif chemokine 17 \\
\hline CCL4 & Secretado & 10,2 & C-C motif chemokine 4 \\
\hline CD151 & Membrana & 28,2 & CD151 Antigen \\
\hline CD99L2 & Membrana plasmática & & CD99 molecule-like 2 (CD99L2) \\
\hline CDK7 & Nuclear & 39 & cyclin-dependent kinase 7 \\
\hline CDKL3 & Citoplasma & 67 & Cyclin-dependent kinase-like 3 \\
\hline CERCAM & Retículo endoplasmatico & 67,5 & \\
\hline CLK3 & Nuclear & 73 & CDC-like kinase 3 (CLK3), transcript variant phclk3/152 \\
\hline CNNM3 & Membrana & 76 & Metal transporter CNNM3 \\
\hline
\end{tabular}




\begin{tabular}{|c|c|c|c|}
\hline COG4 & Golgi & 89,6 & Conserved oligomeric Golgi complex subunit 4 \\
\hline CXCL5 & Secretado & 11,9 & \\
\hline CYB5R1 & Membrana & 34 & cytochrome b5 reductase 1 (CYB5R1) \\
\hline CYBC1 & Retículo endoplasmatico & 20,7 & chromosome 17 open reading frame 62 (C17orf62)/ Cytochrome b-245 chaperone 1 \\
\hline DNAJB14 & Nuclear & 42,5 & DnaJ homolog subfamily B member 14 \\
\hline DNAJC30 & Citosol & 25,9 & DnaJ homolog subfamily C member 30 \\
\hline DNAJC7 & Nuclear /Citoplasma & 56 & DnaJ (Hsp40) homolog, subfamily C, member 7 (DNAJC7) \\
\hline DUSP3 & Nuclear & 20,4 & dual specificity phosphatase 3 (vaccinia virus phosphatase VH1-related) (DUSP3) \\
\hline DYRK2 & Nuclear & 66 & $\begin{array}{l}\text { dual-specificity tyrosine-(Y)-phosphorylation regulated kinase } 2 \text { (DYRK2), transcript } \\
\text { variant } 1\end{array}$ \\
\hline EFTUD2 & Nuclear & 116 & elongation factor Tu GTP binding domain containing 2 (EFTUD2) \\
\hline EXO5 & Nuclear /Citoplasma & 41,8 & Uncharacterized protein C1orf176 - Exonuclease V \\
\hline FAF2 & Retículo endoplasmatico & 52,6 & FAS-associated factor 2 \\
\hline FAM122A & & 30,5 & family with sequence similarity $122 \mathrm{~A}$ (FAM122A) \\
\hline FANK1 & Nuclear /Citosol & 38,4 & fibronectin type III and ankyrin repeat domains 1 (FANK1) \\
\hline FCER1A & Membrana & & Fc fragment of IgE, high affinity I, receptor for; alpha polypeptide (FCER1A) \\
\hline FGD6 & Citoesqueleto & 160 & FYVE, RhoGEF and PH domain containing 6 (FGD6) \\
\hline
\end{tabular}




\begin{tabular}{|c|c|c|c|}
\hline & & & \\
\hline FKBP9 & Retículo endoplasmatico & 63 & FK506 binding protein 9, $63 \mathrm{kDa}$ (FKBP9) \\
\hline FKHL18 & Nuclear & 35 & forkhead-like 18 (Drosophila) (FKHL18) \\
\hline FOXRED1 & Mitocondria & 53,8 & FAD-dependent oxidoreductase domain containing 1 (FOXRED1) \\
\hline FOXS1 & Nuclear & 35,4 & \\
\hline GDE1 & Membrana plasmática & 37,7 & Glycerophosphodiester phosphodiesterase 1 \\
\hline $\mathrm{GH} 2$ & Região extracelular & & growth hormone $2(\mathrm{GH} 2)$, transcript variant 1 \\
\hline GJB4 & Membrana & 30,4 & gap junction protein, beta 4 (GJB4) \\
\hline GNB1L & Membrana & 35,6 & guanine nucleotide binding protein (G protein), beta polypeptide 1-like (GNB1L) \\
\hline GNMT & Citoplasma & 32,7 & glycine N-methyltransferase (GNMT) \\
\hline GNPAT & Peroxissomo & 77 & Dihydroxyacetone phosphate acyltransferase \\
\hline GON7 & Nuclear & 10,8 & chromosome 14 open reading frame 142 (C14orf142) \\
\hline GPRC5C & Membrana & 48,1 & G-protein coupled receptor family C group 5 member C \\
\hline GSK3B & Nuclear & 46,7 & Glycogen synthase kinase-3 beta \\
\hline GSTM3 & Citoplasmática & 26,5 & glutathione S-transferase M3 (brain) (GSTM3) \\
\hline GSTP1 & Nuclear /Mitocondria & 23,8 & glutathione S-transferase pi (GSTP1) \\
\hline GTF2B & Nuclear & 34,8 & Transcription initiation factor IIB \\
\hline GTPBP8 & Mitocondria & 32,1 & GTP-binding protein 8 \\
\hline
\end{tabular}




\begin{tabular}{|c|c|c|c|}
\hline & & & \\
\hline H1F0 & Nuclear & 20,8 & $\mathrm{H} 1$ histone family, member 0 (H1F0) \\
\hline HACD1 & Retículo endoplasmatico & 32,8 & Very-long-chain (3R)-3-hydroxyacyl-CoA dehydratase 1 \\
\hline HAUS8 & Citoesqueleto/Citosol & 44,8 & HAUS augmin-like complex subunit 8 \\
\hline HDDC2 & & 23 & HD domain containing 2 (HDDC2) \\
\hline HEYL & Nuclear & 35,8 & hairy/enhancer-of-split related with YRPW motif-like (HEYL) \\
\hline HMG14 & Nuclear & 10,6 & \\
\hline HMGN2 & Nuclear & 9,3 & Non-histone chromosomal protein HMG-17 \\
\hline HOMER3 & Citoplasmática & 39 & homer homolog 3 (Drosophila) (HOMER3) \\
\hline $\mathrm{HSH} 2 \mathrm{D}$ & Nuclear & 39 & hematopoietic $\mathrm{SH} 2$ domain containing (HSH2D) \\
\hline HSPA1L & Citosol/Nuclear & 70 & heat shock 70kDa protein 1-like (HSPA1L) \\
\hline ICK & Nuclear/Citosol/Citoesqueleto & 70 & Serine/threonine-protein kinase ICK \\
\hline KIAA1568 & Membrana & 151 & Roundabout homolog 2 \\
\hline KLK7 & Secretado & 27,5 & kallikrein-related peptidase 7 (KLK7), transcript variant 1 \\
\hline LCMT1 & Citosol/Nuclear & 38,3 & Leucine carboxyl methyltransferase 1 \\
\hline LYSMD2 & & 23,4 & LysM, putative peptidoglycan-binding, domain containing 2 (LYSMD2) \\
\hline MAPK10 & Nuclear/Mitocondrial & 52 & mitogen-activated protein kinase 10 (MAPK10), transcript variant 1 \\
\hline MARK1 & Citoplasmática & 89 & Serine/threonine-protein kinase MARK1 \\
\hline
\end{tabular}




\begin{tabular}{|c|c|c|c|}
\hline MMAB & Mitocondria & 27,8 & $\begin{array}{l}\text { methylmalonic aciduria (cobalamin deficiency) cblB type (MMAB), nuclear gene } \\
\text { encoding mitochondrial protein }\end{array}$ \\
\hline MOXD1 & Retículo endoplasmatico & 69,7 & DBH-like monooxygenase protein 1 \\
\hline MTAP & Nuclear & 31,2 & methylthioadenosine phosphorylase (MTAP) \\
\hline NARG1L & Nuclear/Citoplasma & 101 & NMDA receptor regulated 1-like (NARG1L), transcript variant 1 \\
\hline NIPA2 & Endossomo/Membrana & & non imprinted in Prader-Willi/Angelman syndrome 2 (NIPA2), transcript variant 1 \\
\hline NIT2 & Citoplasma & 30,6 & nitrilase family, member 2 (NIT2) \\
\hline NOLA1 & Nucleo & 22 & $\begin{array}{l}\text { nucleolar protein family A, member } 1 \text { (H/ACA small nucleolar RNPs) (NOLA1), } \\
\text { transcript variant } 1\end{array}$ \\
\hline PAK 1 & Membrana & & Serine/threonine-protein kinase PAK 1 \\
\hline PAK2 & Citoplasma/Membrana/Nucleo & 58 & p21 (CDKN1A)-activated kinase 2 (PAK2) \\
\hline PARVG & Membrana/Citoesqueleto & & parvin, gamma (PARVG) \\
\hline PCGF3 & Nuclear & 28,1 & polycomb group ring finger 3 (PCGF3) \\
\hline PDGFRA & Membrana & 122 & platelet-derived growth factor receptor, alpha polypeptide (PDGFRA) \\
\hline PDRG1 & Citoplasma & 15 & p53 and DNA damage regulated 1 (PDRG1) \\
\hline
\end{tabular}




\begin{tabular}{|c|c|c|c|}
\hline PDYN & Secretado & 28,3 & prodynorphin (PDYN) \\
\hline PHTF2 & Nuclear & 88 & putative homeodomain transcription factor 2 (PHTF2) \\
\hline PIP4K2A & membrana/nucleo/citoplasma & 46 & phosphatidylinositol-5-phosphate 4-kinase, type II, alpha (PIP4K2A) \\
\hline PITPNC1 & Citoplasma & 38,3 & phosphatidylinositol transfer protein, cytoplasmic 1 (PITPNC1), transcript variant 2 \\
\hline PLCD1 & Citosol & 85 & 1-phosphatidylinositol-4,5-bisphosphate phosphodiesterase delta-1 \\
\hline PLDN & Membrana/ Citoplasma & 19,4 & pallidin homolog (mouse) (PLDN) \\
\hline PLK1 & Nuclear & 68,2 & Serine/threonine-protein kinase PLK1 \\
\hline PLLP & Membrana & 19,8 & Plasmolipin \\
\hline PLSCR1 & Nuclear/Membrana & 35 & phospholipid scramblase 1 (PLSCR1) \\
\hline PNKD & Nuclear/Mitocondrial & 42,8 & paroxysmal nonkinesigenic dyskinesia (PNKD), transcript variant 1 \\
\hline PNOC & Extracelular & & prepronociceptin (PNOC) \\
\hline PPAP2C & Membrana & 32,7 & phosphatidic acid phosphatase type $2 \mathrm{C}$ (PPAP2C), transcript variant 1 \\
\hline PPARG & Nuclear & 57,6 & Peroxisome proliferator-activated receptor gamma \\
\hline PPIG & Nuclear & 88 & Peptidyl-prolyl cis-trans isomerase G \\
\hline PPP1R14A & Citoplasma & 16 & protein phosphatase 1 , regulatory (inhibitor) subunit 14A (PPP1R14A) \\
\hline PRKD1 & Golgi/Membrana/Citoplasma & 101 & Serine/threonine-protein kinase D1 \\
\hline RAB22A & Endossomo & 21,8 & RAB22A, member RAS oncogene family (RAB22A) \\
\hline
\end{tabular}




\begin{tabular}{|c|c|c|c|}
\hline & & & \\
\hline RAB24 & Citosol & 23,4 & RAB24, member RAS oncogene family (RAB24) \\
\hline RAB3B & Membrana plasmática & 27 & RAB3B, member RAS oncogene family (RAB3B) \\
\hline RAD51 & Nuclear & 42,1 & DNA repair protein RAD51 homolog 1 \\
\hline RASD2 & Membrana & 32,3 & RASD family, member 2 (RASD2) \\
\hline RBJ & Nuclear & 30,8 & rab and DnaJ domain containing (RBJ) \\
\hline RCOR2 & Nuclear & 58 & REST corepressor 2 (RCOR2) \\
\hline RFX3 & Nuclear & 83 & regulatory factor X, 3 (influences HLA class II expression) (RFX3), transcript variant 2 \\
\hline RHOA & Membrana /Citoplasma & 21,4 & ras homolog gene family, member $\mathrm{A}(\mathrm{RHOA})$ \\
\hline RLN1 & Extracelular/ Secretado & 18,4 & relaxin 1 (RLN1) \\
\hline RNF111 & Nuclear & 108 & E3 ubiquitin-protein ligase Arkadia \\
\hline ROS1 & Membrana & 261 & v-ros UR2 sarcoma virus oncogene homolog 1 (avian) (ROS1) \\
\hline RPL26L1 & Citosol & 17 & ribosomal protein L26-like 1 (RPL26L1) \\
\hline RRAGD & Citplasma /Nuclear & 45,6 & Ras-related GTP binding D (RRAGD) \\
\hline SAR1B & Retículo/Golgi & 22,4 & SAR1 gene homolog B (S. cerevisiae) (SAR1B), transcript variant 2 \\
\hline SCAMP1 & Endossomo/Golgi & 34,9 & secretory carrier membrane protein 1 (SCAMP1) \\
\hline SECISBP2 & Nuclear/Mitocondria & 95 & Selenocysteine insertion sequence-binding protein 2 \\
\hline SEMA4G & Membrana & 94,1 & sema domain, immunoglobulin domain (Ig), transmembrane domain (TM) and short \\
\hline
\end{tabular}




\begin{tabular}{|c|c|c|c|}
\hline & & & cytoplasmic domain, (semaphorin) 4G (SEMA4G) \\
\hline SERPIND1 & Retículo & 57 & serpin peptidase inhibitor, clade D (heparin cofactor), member 1 (SERPIND1) \\
\hline \multirow[t]{2}{*}{ SERPINE2 } & Extracelular/Secretado & 42,8 & $\begin{array}{l}\text { serpin peptidase inhibitor, clade } E \text { (nexin, plasminogen activator inhibitor type } 1 \text { ), } \\
\text { member } 2\end{array}$ \\
\hline & & & (SERPINE2) \\
\hline SFXN2 & Mitocondria & 36,2 & sideroflexin 2 (SFXN2) \\
\hline SLC22A23 & Membrana & 44,7 & Solute carrier family 22 member 23 \\
\hline SLC39A8 & Membrana & 46,7 & Putative sodium-coupled neutral amino acid transporter 8 \\
\hline SNN & & & stannin (SNN) \\
\hline SNX4 & Endossomo & 51,9 & sorting nexin 4 (SNX4) \\
\hline SP2 & Nuclear & 64,9 & Sp2 transcription factor (SP2) \\
\hline SPANXB1 & Nuclear & 11,8 & SPANX family, member B1 (SPANXB1) \\
\hline SPN & Nuclear & 40,3 & sialophorin (leukosialin, CD43) (SPN), transcript variant 2 \\
\hline SPON2 & Extracelular/Secretado & 40,8 & SPONDIN-2 \\
\hline SSPN & Membrana & 26,6 & sarcospan (Kras oncogene-associated gene) (SSPN) \\
\hline SUGT1L1 & & & SGT1, suppressor of G2 allele of SKP1 like 1 (S. cerevisiae) (SUGT1L1) \\
\hline SUSD3 & Membrana & 27 & sushi domain containing 3 (SUSD3) \\
\hline
\end{tabular}




\begin{tabular}{|c|c|c|c|}
\hline SYDE1 & Citoplasmatica & 79,7 & Rho GTPase-activating protein SYDE1 \\
\hline $\begin{array}{c}\text { Synembryn- } \\
\text { A }\end{array}$ & Membrana & 59,7 & Synembryn-A \\
\hline TBX22 & Nuclear & 57,9 & T-box 22 (TBX22) \\
\hline TCTEX1D2 & Citoesqueleto & 16,2 & Tctex 1 domain-containing protein 2 \\
\hline TEDC2 & & 46,4 & Tubulin epsilon and delta complex protein 2 \\
\hline TIMD4 & Membrana & 41,5 & T-cell immunoglobulin and mucin domain-containing protein 4 \\
\hline TK1 & Citosol/Mitocondria & 25,4 & Thymidine kinase, cytosolic \\
\hline TMEM192 & Lisossomo/Endossomo & 30,9 & Transmembrane protein 192 \\
\hline TMEM40 & MEMBRANA & & Transmembrane protein 40 \\
\hline TRIB2 & Citoesqueleto/Citoplasma & 38,8 & tribbles homolog 2 (Drosophila) (TRIB2) \\
\hline TRIM47 & Nuclear & 69,5 & tripartite motif-containing 47 (TRIM47) \\
\hline TRIM65 & Nuclear/Citosólica & 57 & tripartite motif-containing 65 (TRIM65) \\
\hline TSR2 & Nuclear & 20,8 & TSR2, 20S rRNA accumulation, homolog (S. cerevisiae) (TSR2) \\
\hline UBD & Nuclear/Citoplasmática & 18,4 & ubiquitin $\mathrm{D}$ (UBD) \\
\hline UBE1C & Citosol/Nuclear & 51,8 & ubiquitin-activating enzyme E1C (UBA3 homolog, yeast) (UBE1C), transcript variant 3 \\
\hline UNKL & Nuclear & 73,8 & unkempt homolog (Drosophila)-like (UNKL) \\
\hline
\end{tabular}




\begin{tabular}{ccll}
\hline UTS2B & Extracelular & 13,7 & Urotensin-2B \\
VDAC1 & Membrana & 30,1 & voltage-dependent anion channel 1 (VDAC1) \\
VEGFD & Secretado & 40,4 & Vascular endothelial growth factor D \\
WIF1 & Região extracelular & 41,5 & WNT inhibitory factor 1 (WIF1) \\
Wnt-3 & extracelular ou secretado & & Proto-oncogene protein Wnt-3 \\
ZBED1 & Nuclear & 78,1 & Zinc finger BED domain-containing protein 1 \\
\hline
\end{tabular}

